\title{
Development of Improved Iron Fischer-Tropsch Catalysts
}

\author{
Quarterly Technical Progress Report \\ for the Period 1 October 1991 - 31 December 1991
}

Texas A\&M Research Foundation Project 6464

\author{
Prepared by: Dragomir B. Bukur \\ Contributors: X. Lang \\ K. Okabe
}

Texas A\&M University

Department of Chemical Engineering

College Station, Texas 77843-3122

January 10, 1992

Prepared for the Pittsburgh Energy Technology Center, the United States Department of Energy Under Contract No. DE-AC22-89PC89868 V. Udaya Rao, Project Manager (PETC)

"U.S. Department of Energy Patent Clearance not required prior to publication of this document" 


\section{NOTICE}

This report was prepared as an account of work sponsored by an agency of the United States

Government. Neither the United States nor any agency thereof, nor any of their employees, makes any warranty, expressed or implied, or assumes any legal liability or responsibility of any third party's results of such use of any information, apparatus, product or process disclosed in this report, or represents that its use by such a third party would not infringe privately owned rights.

\section{PATENT STATUS}

U.S./DOE Patent Clearance is not required prior to the publication of this document.

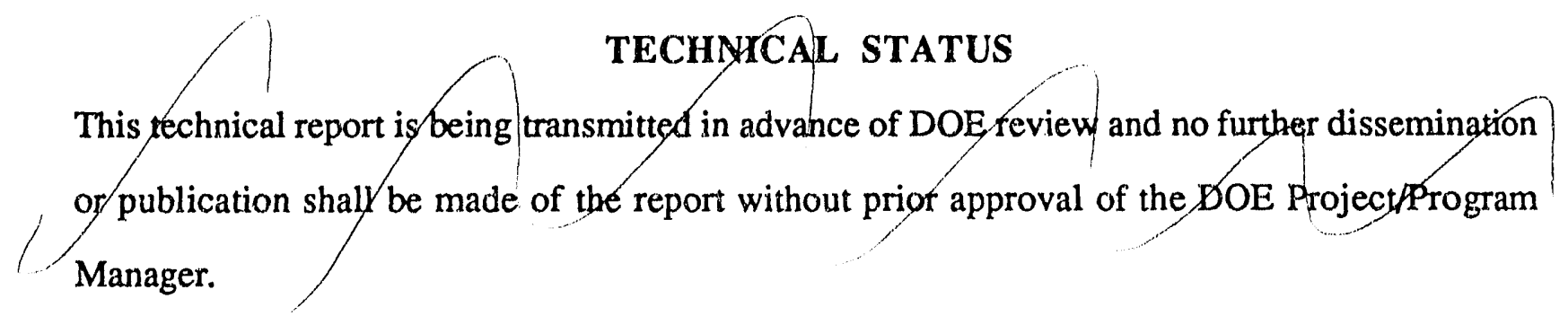




\section{TABLE OF CONTENTS}

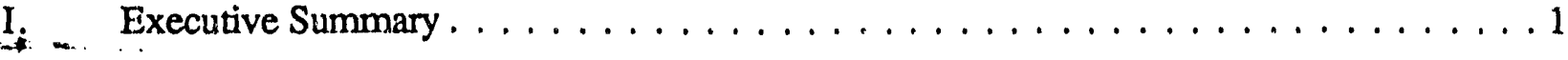

II. Objective and Scope of Work $\ldots \ldots \ldots \ldots \ldots \ldots \ldots \ldots \ldots \ldots$

III. Detailed Description of Technical Progress $\ldots \ldots \ldots \ldots \ldots \ldots \ldots$

III-1. Task 2. Catalyst Pretreatment Research . . . . . . . . . . . . . . .

III-1.1 Run FB-3221 (100Fe/0.3Cu/0.8K catalyst $) \ldots \ldots \ldots \ldots \ldots \ldots$

III-2. Task 3. Improved Iron/Silica Catalysts . . . . . . . . . . . . . . . 5

III-2.1 Run SB-3101 (100Fe/5Cu/8K/24SiO 2 catalyst $) \ldots \ldots \ldots \ldots \ldots \ldots$

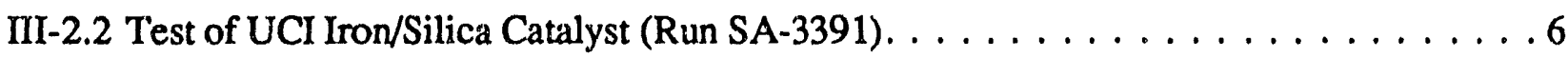

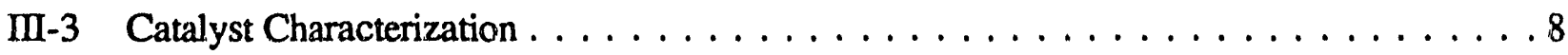

Tables ............................... 12

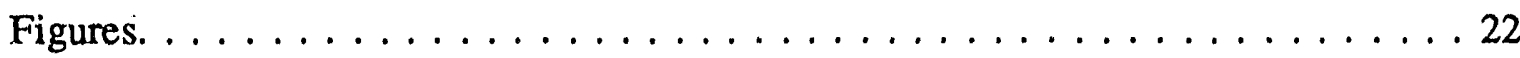




\section{Executive Summary}

Three catalyst evaluation tests (one in a fixed bed reactor, and two in a stirred tank slurry reactor) were completed during the reporting period. Also, the progress has been made in the area - ... of characterization of catalysts at various stages of their usage (as prepared, after calcination, reduction or Fischer-Tropsch synthesis).

Pretreatment effect studies in a fixed bed reactor on performance of a precipitated catalyst with nominal composition $100 \mathrm{Fe} / 0.3 \mathrm{Cu} / 0.8 \mathrm{~K}$ have been continued. This catalyst was evaluated at $250^{\circ} \mathrm{C}, 200 \mathrm{psig}, 2 \mathrm{Nl} / \mathrm{g}$-cat $/ \mathrm{h}$ and $\mathrm{H}_{2} / \mathrm{CO}=0.66$ after reduction with $\mathrm{H}_{2}$ at $280^{\circ} \mathrm{C}, 3 \mathrm{Nl} / \mathrm{g}$-cat/h for $8 \mathrm{~h}$ in a test designated FB-3221. Catalyst activity increased gradually between $50 \mathrm{~h}$ (50\% conversion) and $150 \mathrm{~h}$ on stream ( $57.5 \%$ conversion), whereas hydrocarbon product distribution was fairly stable; $\left(\mathrm{CH}_{4}\right)=6.8,\left(\mathrm{C}_{2}-\mathrm{C}_{4}\right)=22.4,\left(\mathrm{C}_{5}-\mathrm{C}_{11}\right)=33.1$ and $\mathrm{C}_{12}{ }^{+}=37.7 \%$. These trends are consistent with results obtained in our previous studies with this, as well as with other precipitated iron catalysts. Also, this catalyst was characterized by XRD after various pretreatment procedures in a fixed bed reactor. Iron phases in $\mathrm{H}_{2}$ reduced samples were identified as: either a mixture of $\mathrm{Fe}_{3} \mathrm{O}_{4}$ and $\mathrm{Fe}$ (reductions at $220^{\circ} \mathrm{C}$ and $280^{\circ} \mathrm{C}$ ) or metallic iron $\left(250^{\circ} \mathrm{C}\right.$ at high flow rate of $\left.\mathrm{H}_{2}\right)$. In samples activated with $\mathrm{CO}$ or syngas $\left(280^{\circ} \mathrm{C}\right.$ or $\left.310^{\circ} \mathrm{C}\right)$ the main phase present was $\chi$ carbide.

Silica containing precipitated iron catalyst with nominal composition $100 \mathrm{Fe} / 5 \mathrm{Cu} / 8 \mathrm{~K} / 24 \mathrm{SiO}_{2}$ was evaluated in a slurry reactor test $\mathrm{SB}-3101$ at $260^{\circ} \mathrm{C}, 200 \mathrm{psig}, 1.6 \mathrm{~N} / / \mathrm{g}$ cat $/ \mathrm{h}$ and $\mathrm{H}_{2} / \mathrm{CO}=0.64$. The $\left(\mathrm{H}_{2}+\mathrm{CO}\right)$ conversion decreased gradually from about $77 \%$ to $60 \%$ at $350 \mathrm{~h}$ on stream, whereas methane selectivity increased with time from 4.2 to $5.5 \%$.

At the request of DOE's Liquefaction Project Management an iron/silica precipitated catalyst synthesized at United Catalysts Inc. was evaluated in a slurry reactor test SA-3391. After some initial problems with our experimental apparatus, the desired process conditions $\left(265^{\circ} \mathrm{C}, 290 \mathrm{psig}\right.$, $2.4 \mathrm{~N} / / \mathrm{g}$-cat $/ \mathrm{h}, \mathrm{H}_{2} / \mathrm{CO}=0.70$ ) were established at about $200 \mathrm{~h}$ on stream. During $110 \mathrm{~h}$ of testing at these conditions the $\left(\mathrm{H}_{2}+\mathrm{CO}\right)$ conversion varied between 71 and $75 \%$, whereas methane selectivity was between 4.2 and $4.6 \%$. Similar results (activity and methane selectivity) were obtained in a test of the same catalyst conducted at UOP Inc. 


\section{Objective and Scope of Work}

The objective of proposed research is development of catalysts with enhanced slurry phase activity and better selectivity to fuel range products, through a more detailed understanding and systematic studies of the effects of pretreatment procedures and promoters/binders (silica) on catalyst performance. In order to accomplish this objective, the work shall be divided into several tasks which are described in the following subsections.

\section{Task 1 - Project Management}

Within 60 days of project initiation, the contractor shall prepare and submit to the DOE Project Manager a detailed project work plan covering the entire period of performance of the project. The plan shall present, in detail, all activities that will be performed to successfully complete proposed research and it shall consist of the following: (1) detailed description of the methods and technical approach that shall be used to achieve the objectives of this project; (2) a detailed project schedule for each task or other logical segment of work to be performed; (3) graphs reflecting cumulative estimated costs and person-hour expended by month for each task or other logical segment of work, and for the total project effort; (4) a project work chart showing the key personnel/groups planned to work on each task and percentage of their time devoted to the tasks; and (5) a Work Breakdown Structure (WBS) dictionary to establish the framework for contract execution and to report cost schedule and technical performance.

All project status, milestone schedule, and cost management reports, as well as topical reports, if any, shall be submitted in accordance with the DOE reporting requirements.

\section{Task 2 - Catalyst Pretreatment Research}

This task is aimed at developing optimal pretreatment conditions for precipitated unsupported (1 catalyst) and supported (or silica containing; 1-2) iron catalysts, and at providing a better understanding of the role of pretreatment on subsequent catalyst activity, selectivity and longevity 
during Fischer-Tropsch synthesis (FTS). This shall be accomplished by examining the effect of yarious activation conditions on physical and chemical properties of the catalyst as well as on catalytic behavior in fixed and slurry bed reactors. Parameters such as type of reductant $\mathrm{CH}_{2}$ vs. $\mathrm{CO}$ vs. syngas), reductant flow rate, temperature and duration shall be studied. Selected catalysts shall be extensively characterized using a variety of physical, chemical and instrumental techniques with the objective to establish correlations between the physical/chemical properties of the catalysts and their observed catalytic behavior during FTS.

\section{Task 3 - Improved Iron Silica Catalyst}

The objective of this task is to determine optimal concentrations of silica and $\mathrm{K}_{2} \mathrm{O}$ in a catalyst with composition $100 \mathrm{Fe} / \mathrm{x} \mathrm{Cu} / \mathrm{y} \mathrm{K}_{2} \mathrm{O} / \mathrm{z} \mathrm{SiO}_{2}$ (in parts per weight). The effect of $\mathrm{SiO}_{2}$ and $\mathrm{K}_{2} \mathrm{O}$ on catalytic activity, selectivity and stability shall be determined to arrive at promoter/binder concentrations for an improved catalyst performance. The screening tests shall be conducted in fixed bed reactors to obtain preliminary indication of F-T activity and selectivity at different process conditions. Catalysts which show enhanced activity and/or selectivity towards transportation fuels shall be tested in slurry reactors up to 30 days on stream. Selected catalysts shall be extensively characterized, to determine relations between the physico-chemical properties of catalyst and their catalytic behavior during F-T synthesis. 


\section{DETAILED DESCRIPTION OF TECHNICAL PROGRESS}

\section{III-1. Task 2. Catalyst Pretreatment Research}

A fixed bed test was conducted with a precipitated iron catalyst $(100 \mathrm{Fe} / 0.3 \mathrm{Cu} / 0.8 \mathrm{~K})$ to continue the investigation of pretreatment condition effects on catalyst activity, selectivity and stability. Results from catalyst characterization studies can be found in Section III-3 of this report.

\section{III-1.1 Run FB-3221 with $100 \mathrm{Fe} / 0.3 \mathrm{Cu} / 0.8 \mathrm{~K}$ Catalyst}

Pretreatment conditions employed in this test were: hydrogen reduction at $280^{\circ} \mathrm{C}, 3 \mathrm{~N} / \mathrm{g}-$ $\mathrm{cat} / \mathrm{h}$ and ambient pressure for $8 \mathrm{~h}$. After reduction, the catalyst was tested at average reaction temperature, pressure, gas space velocity and $\mathrm{H}_{2} / \mathrm{CO}$ feed ratio of $250^{\circ} \mathrm{C}, 1.48 \mathrm{MPa}(200 \mathrm{psig}), 2$ $\mathrm{N} l / \mathrm{g}$-cat/h and 0.69 , respectively. The run was terminated voluntarily after $155 \mathrm{~h}$ on stream, and results from three mass balances are summarized in Table 1.

\section{Catalyst Activity and Stability}

Catalyst activity, measured by $\left(\mathrm{H}_{2}+\mathrm{CO}\right)$ conversion and gas volumetric contraction, increased gradually with time-on-stream (Figure 1). For example, the $\left(\mathrm{H}_{2}+\mathrm{CO}\right)$ conversion at $50 \mathrm{~h}$ on stream was $50 \%$, and $57 \%$ at $150 \mathrm{~h}$. The water gas shift (WGS) activity of the catalyst was high, and the $\left(\mathrm{H}_{2} / \mathrm{CO}\right)$ usage ratio varied between 0.58 to 0.66 throughout the test.

\section{Hydrocarbon Selectivity}

The average hydrocarbon product distribution (from three mass balances in Table 1) was: $6.8\left(\mathrm{CH}_{4}\right), 22.4\left(\mathrm{C}_{2}-\mathrm{C}_{4}\right), 33.1\left(\mathrm{C}_{5}-\mathrm{C}_{11}\right)$ and $37.6 \mathrm{wt} \%\left(\mathrm{C}_{12}{ }^{+}\right)$.

A typical carbon number distribution, in the form of Anderson-Shulz-Flory (ASF) plot, is shown in Figure 2. The chain growth parameter for products in $C_{1}-C_{11}$ range is 0.70 . Solid product (wax) collected in a high pressure trap was not analyzed.

Methane and gaseous hydrocarbons selectivities obtained in this test were higher than those obtained in test FB-0021 (Quarterly Report for January - March, 1991) where CO reduction was 
used (other pretreatment and process conditions were the same as in this test). However, with $\mathrm{H}_{2}$

- . reqduction the catalyst activity increased with TOS, whereas the opposite trend was observed when $\mathrm{CO}$ reduction was employed.

\section{III-2. Task 3. Improved Iron/Silica Catalysts}

\section{III-2.1 Run SB-3101 with $100 \mathrm{Fe} / 5 \mathrm{Cu} / 8 \mathrm{~K} / 24 \mathrm{SiO}{ }_{2}$ Catalyst}

This was the first slurry reactor test of this catalyst. Process conditions were: $260^{\circ} \mathrm{C}, 200$ psig, $1.6 \mathrm{Nl} / \mathrm{g}$-cat $/ \mathrm{h}$ and $\mathrm{H}_{2} / \mathrm{CO}=0.64$ throughout the entire test. A feed flowrate upset occurred at about $158 \mathrm{~h}$, but it was corrected immediately by increasing slightly the cylinder delivery pressure. The run was terminated after $354 \mathrm{~h}$ on stream. Results from six mass balances made during the test are summarized in Table 2, whereas major events are listed in Table 3.

\section{Catalyst Activity and Selectivity}

The catalyst deactivated continuously with time on stream. The $\left(\mathrm{H}_{2}+\mathrm{CO}\right)$ conversion decreased from initial value of $77 \%$ to $60 \%$ at $350 \mathrm{~h}$ on stream, while volumetric contraction (VC) decreased from $50 \%$ to $38 \%$ during the same time period. Changes of $\left(\mathrm{H}_{2}+\mathrm{CO}\right)$ conversion and VC with time on stream are shown in Figure 3. WGS activity of the catalyst was high, and the $\left(\mathrm{H}_{2} / \mathrm{CO}\right)$ usage ratio varied between 0.56-0.58.

\section{Wax and Catalyst Withdrawals/Inventories}

Wax was withdrawn periodically through a porous sintered metal filter with nominal pore size of $0.5 \mu \mathrm{m}$. No catalyst was found in the withdrawn wax. The wax production rate decreased from 1.4 to $1.0 \mathrm{~g} / \mathrm{h}$ as the catalyst deactivated with time.

At the end of the run, $8.5 \mathrm{~g}$ of catalyst was recovered from the reactor slurry. Another estimated $2.4 \mathrm{~g}$ of catalyst was removed from the reactor during the test with slurry samples for catalyst characterization. Catalyst recovery was about $92 \%$, whereas wax recovery was $101 \%$ based on the amounts of catalyst and wax charged into the reactor. 


\section{Hydrocarbon Selectivity}

Hydrocarbon product distribution shifted gradually toward lower molecular weight products with time on stream. For example, at $40 \mathrm{~h}$ on stream, hydrocarbon selectivity was $\left(\mathrm{C} \mathrm{H}_{4}\right)=4.2,\left(\mathrm{C}_{2}-\mathrm{C}_{4}\right)=14.6,\left(\mathrm{C}_{5}-\mathrm{C}_{11}\right)=25$ and $\mathrm{C}_{12}{ }^{+}=56.2 \mathrm{wt} \%$, while at $340 \mathrm{~h}$, it became $\left(\mathrm{CH}_{4}\right)=5.5 \%,\left(\mathrm{C}_{2}-\mathrm{C}_{4}\right)=16.5,\left(\mathrm{C}_{5}-\mathrm{C}_{11}\right)=23$ and $\mathrm{C}_{12}{ }^{+}=55 \mathrm{wt} \%$.

A typical carbon number product distribution is shown in Figure 4 in the form of ASF plot. This plot is based on products collected overhead (i.e. the wax from the reactor was not analyzed).

\section{III-2.2 Run SA-3391 with UCI Iron/Silica Catalyst}

This test was conducted as part of DOE/PETC coordinated program for evaluating one of iron/silica catalysts synthesized by United Catalysts Inc. (UCI). The nominal composition of this catalyst is $100 \mathrm{Fe} / 4.3 \mathrm{Cu} / 8 \mathrm{~K} / 17 \mathrm{SiO}_{2}$. The same catalyst was tested in a stirred tank slurry reactor at UOP.

About 25g of this catalyst was loaded as received (without calcination), and $330 \mathrm{~g}$ of ETHYLFLO ${ }^{\text {TM }} 164$ oil was employed as the initial slurry medium. After sealing of the reactor nitrogen was introduced at $153 \mathrm{psig}$ and stirring was initiated at $1100 \mathrm{rpm}$. Then the slurry temperature was raised linearly to $280^{\circ} \mathrm{C}$ in 3 hours under nitrogen flow. When $280^{\circ} \mathrm{C}$ was reached, the nitrogen flow was replaced with synthesis gas $\left(\mathrm{H}_{2} / \mathrm{CO}=0.7\right)$, and the catalyst was pretreated at $280^{\circ} \mathrm{C}, 153 \mathrm{psig}, 2.0 \mathrm{~N} / \mathrm{g}-\mathrm{Fe} / \mathrm{h}$ for $12 \mathrm{~h}$. After the pretreatment the catalyst was tested at $265^{\circ} \mathrm{C}$ (it was found later that the actual temperature was $270^{\circ} \mathrm{C}$ ), $290 \mathrm{psig}, 3.0 \mathrm{~N} / \mathrm{g}-\mathrm{Fe} / \mathrm{h}$ and $\mathrm{H}_{2} \mathrm{CO}=0.70$ for the first $100 \mathrm{~h}$ (mass balances $1 \& 2$ ). At about $103 \mathrm{~h}$ on stream, the gas space velocity was lowered from 3.0 to $2.4 \mathrm{~N} / \mathrm{g}$-Fe/h (mass balance 3 ). After the third balance, the temperatures of the reactor head and the exit line were decreased by $30-40^{\circ} \mathrm{C}$ while the process conditions were unchanged (mass balance 4). At 193h on stream, the reactor temperature was lowered to actual $265^{\circ} \mathrm{C}$ (mass balance 5). The feed was switched to premixed synthesis gas $\left(\mathrm{H}_{2} / \mathrm{CO}=0.67\right)$ at $287 \mathrm{~h}$ (mass balance 6$)$, and the test was terminated voluntarily after $310 \mathrm{~h}$ on 
stream. Results from six mass balances made during the test are summarized in Table 4, whereas major events are listed in Table 5 .

\section{Catalyst Activity and Stability}

Changes in $\left(\mathrm{H}_{2}+\mathrm{CO}\right)$ conversion and $\mathrm{VC}$ with time-on-stream at various process conditions are shown in Figure 5. After reaching the initial process conditions of $265^{\circ} \mathrm{C}\left(270^{\circ} \mathrm{C}\right.$ actual), $290 \mathrm{psig}, 3.0 \mathrm{~N} / / \mathrm{g}-\mathrm{Fe} / \mathrm{h}$, the $\left(\mathrm{H}_{2}+\mathrm{CO}\right)$ conversion increased gradually from $76 \%$ at $3 \mathrm{~h}$ to $80 \%$ at $24 \mathrm{~h}$, then it remained stable during the next $80 \mathrm{~h}$ of testing. At about $103 \mathrm{~h}$, gas flow rate was decreased ( $\mathrm{SV}=2.4 \mathrm{~N} / \mathrm{g}-\mathrm{Fe} / \mathrm{h}$ ) in order to test the catalyst under the same conditions as those employed at UOP. Consequently, the $\left(\mathrm{H}_{2}+\mathrm{CO}\right)$ conversion increased to $82-83 \%$ and was stable during the next $60 \mathrm{~h}$ on stream. Since our values of the $\left(\mathrm{H}_{2}+\mathrm{CO}\right)$ conversion $(83 \%)$ and methane selectivity $(\sim 8 \%)$ were significantly greater than those obtained at UOP $(70 \%$ and $4.0 \%$, respectively) we suspected that there may be some problems with our apparatus. The $\left(\mathrm{H}_{2}+\mathrm{CO}\right)$ conversion decreased to $79 \%$, when temperature of the reactor head was decreased from 270 to $230^{\circ} \mathrm{C}$ and that of the exit line from 250 to $210^{\circ} \mathrm{C}$ at $170 \mathrm{~h}$ on stream, whereas the slurry temperature was maintained at $265^{\circ} \mathrm{C}$ (i.e. $270^{\circ} \mathrm{C}$ ). An error in the temperature readout device was confirmed at this time. At $196 \mathrm{~h}$, the reactor temperature was corrected from 270 to $265^{\circ} \mathrm{C}$, and the $\left(\mathrm{H}_{2}+\mathrm{CO}\right)$ conversion decreased further to $75 \%$. During remaining $110 \mathrm{~h}$ of testing (196 to $310 \mathrm{~h}$ ), the catalyst activity decreased slowly with time. For example, the $\left(\mathrm{H}_{2}+\mathrm{CO}\right)$ conversion was about $71.5 \%$ at $310 \mathrm{~h}$. These conversions are similar to those obtained at UOP.

WGS activity of the catalyst was high and stable throughout the entire test. The usage ratio varied between 0.56 to 0.61 .

\section{Wax and Catalyst Withdrawals/Inventories}

The withdrawals were made daily through a porous metal filter at an initial pressure drop across the filter of 15 psig during the first 2-3 days of testing. However, after four days on stream the pressure drop had to be increased to $80 \mathrm{psig}$ in order to facilitate wax withdrawal. No catalyst 
was found in the withdrawn wax. During the test, three slurry samples were withdrawn for future catalyst characterization.

At the end of the run, about $268 \mathrm{~g}$ of wax was recovered from the reactor, whereas the initial amount (after the slurry sample and wax withdrawals following the pretreatment) was estimated to be $235 \mathrm{~g}$. This discrepancy is partly due to different gas hold-up in the slurry at the beginning and at the end of the test (different feed flow rate and slurry temperature).

\section{Hydrocarbon Selectivity}

The initial methane selectivity was about $4.2 \mathrm{wt} \%$ (at $3 \mathrm{~h}$ on stream). Then it increased continuously with time during the next $150 \mathrm{~h}$. For example, at $140 \mathrm{~h}\left(270^{\circ} \mathrm{C}, 290 \mathrm{psig}, 2.4 \mathrm{~N} / \mathrm{g}\right.$ $\mathrm{Fe} / \mathrm{h}$ ) hydrocarbon selectivity was $\left(\mathrm{CH}_{4}\right)=8.2,\left(\mathrm{C}_{2}-\mathrm{C}_{4}\right)=17.5,\left(\mathrm{C}_{5}-\mathrm{C}_{11}\right)=20.0$ and $\mathrm{C}_{12}{ }^{+}=$ $45.6 \mathrm{wt} \%$. However, methane selectivity immediately dropped to $5.3 \mathrm{wt} \%$ when temperatures of the reactor head and exit line were decreased by $30-40^{\circ} \mathrm{C}$ (after $173 \mathrm{~h}$ ). It seems that a hot spot existed along the exit line which either caused cracking of hydrocarbon products to methane, or catalyzed FT synthesis reaction (but mainly forming $\mathrm{C} 1-\mathrm{C} 2$ products because of short contact time). After correcting the reactor temperature to $265^{\circ} \mathrm{C}$, methane selectivity decreased further. The average hydrocarbon product distribution from the last two mass balances made at $265^{\circ} \mathrm{C}, 290$ psig, $2.4 \mathrm{~N} l / \mathrm{g}-\mathrm{Fe} / \mathrm{h}, \mathrm{H}_{2} / \mathrm{CO}=0.70-0.67$ was: $\left(\mathrm{CH}_{4}\right)=4.4\left(\mathrm{C}_{2}-\mathrm{C}_{4}\right)=16.5,\left(\mathrm{C}_{5}-\mathrm{C}_{11}\right)=23.6$ and

$\mathrm{C}_{12}{ }^{+}=55.5 \mathrm{wt} \%$. As stated earlier, methane selectivity of about $4.0 \%$ was obtained during testing of this catalyst at UOP.

Carbon number distribution obtained from balance 5 is given in Figure 6, in the form of ASF plot. Wax withdrawn from the reactor was not analyzed, which explains the rapid decrease in concentration of $\mathrm{C}_{17}{ }^{+}$products shown on the plot.

\section{III-3 Catalyst Characterization}

During the current reporting period, residual amounts of potassium in the newly prepared catalysts were determined by atomic absorption (AA). Some of the previously prepared fresh 
catalysts were characterized by surface area/pore size distribution measurement (BET/PSD), and Xray. diffraction (XRD). Also, we have continued our characterization studies of reduced and catalyst samples by XRD. The following sections contain detailed descriptions of progress in each of these areas.

\section{Preparation and Elemental Analysis of Catalysts}

Previously prepared $100 \mathrm{Fe} / 5 \mathrm{Cu} / 100 \mathrm{SiO}_{2}$ catalyst was washed with distilled water again to remove excessive amount of potassium on it, and the composition was determined by $\mathrm{AA}$. In order to check reproducibility of experimental results some other catalyst samples were also measured, and results are summarized in Table 6 . By washing the $100 \mathrm{Fe} / 5 \mathrm{Cu} / 100 \mathrm{SiO}_{2}$ for another week, the residual amount of potassium decreased from 4.6 parts by weight ( $55000-1)$ to 2.1 parts by weight (S5000-2). By further washing, the potassium content decreased to 1.1 parts by weight (S5000-4), although contents of copper and silica were almost unchanged.

Reproducibility of measurements made at TAMU was quite satisfactory, however the potassium content in sample S-5000-1 measured at Galbraith Laboratories Inc. (by ICP) was significantly lower than that obtain at TAMU (2.7 vs. 4.5$)$.

\section{Surface Area and Pore Size Distribution}

Surface areas and pore volumes were measured by physical adsorption of $\mathrm{N}_{2}$ at $77 \mathrm{~K}$, and values obtained are listed in Table 7, whereas differential pore volume distributions are shown in Fig. 7 Surface area (SA) of calcined $100 \mathrm{Fe} / 0.3 \mathrm{Cu} / 0.8 \mathrm{~K}$ catalyst sample (C0308-1) was slightly larger than that of another batch with the same com-sosition $(\mathrm{C} 0308-3)$, and pore volume $\left(\mathrm{v}_{\mathrm{p}}\right)$ was

slightly smaller, resulting in smaller average pore diameter $\left(d_{p}\right)$. A smaller surface area $(\sim 150$ $\mathrm{m}^{2} / \mathrm{g}$ ) was obtained for calcined $100 \mathrm{Fe} / 5 \mathrm{Cu} / 4.2 \mathrm{~K} / 100 \mathrm{SiO}_{2}$ catalyst sample than for other calcined $100 \mathrm{Fe} / 5 \mathrm{Cu} / 4.2 \mathrm{~K} / \mathrm{zSiO}_{2}$ catalyst samples in this series $(\mathrm{z}=0,8,16,24,40)$. For these catalysts the surface areas were between 180 and $260 \mathrm{~m}^{2} / \mathrm{g}$, and the value cbtained with $\mathrm{z}=100$ is believed 
to be in error. The pore volume of $0.83 \mathrm{~cm}^{3} / \mathrm{g}$ was higher than that obtained with catalysts c... containing less silica, which is as expected.

\section{X-Ray Diffraction of Fresh Catalysts}

As-prepared and calcined catalysts with nominal composition of $100 \mathrm{Fe} / 0.3 \mathrm{Cu} / 0.8 \mathrm{~K}$, as well as commercial catalysts (Ruhrchemie and $\mathrm{UCI}$ ), were characterized by XRD. X-ray diffraction patterns depicted in Figure 8 show that the main phase in each of catalyst samples is $\mathrm{Fe}_{2} \mathrm{O}_{3}$. The differences on peak intensity and width indicate differences in crystallite sizes. The crystallite sizes were estimated by the line broadening method and summarized in Table 8 . The peaks of as-prepared $100 \mathrm{Fe} / 0.3 \mathrm{Cu} / 0.8$ catalyst sample (CO308-1) and of the Ruhrchemie catalyst samples were too broad and unresolved to determine the crystallite sizes. It is presumed that these crystallite sizes were less than $50 \AA$. The average crystallite size of as-prepared C0308-3 catalyst was almost the same as of the calcined one, but was significantly greater than that of C0308-1 catalyst. After calcination the difference in crystallite sizes of these two catalyst batches becomes smaller. The larger crystallite size coincides with large pore diameter, as mentioned above. Although the preparation procedure and the chemical compositions of these catalysts were almost the same, as reported previously, there are some differences in their physical properties.

\section{X-Ray Diffraction of Reduced Catalysts}

During the present reporting period, catalyst with nominal composition of $100 \mathrm{Fe} / 0.3 \mathrm{Cu} / 0.8 \mathrm{~K}$ (C-0308-3) was reduced under various conditions, and the pretreatment effects on the initial phases of reduced catalysts were investigated by XRD. Results are summarized in Table 9 and Figures 9 and 10.

Figure 9 shows XRD patterns of the $100 \mathrm{Fe} / 0.3 \mathrm{Cu} / 0.8 \mathrm{~K}$ catalyst after calcination, and reduction with $\mathrm{H}_{2}$ under various conditions. Calcined catalyst showed a typical pattern of $\mathrm{Fe}_{2} \mathrm{O}_{3}$. After reduction with $\mathrm{H}_{2}$ at $220^{\circ} \mathrm{C}$ for $1 \mathrm{~h}$, this phase changed into $\mathrm{Fe}_{3} \mathrm{O}_{4}$ mainly. At a higher reduction temperature $\left(250^{\circ} \mathrm{C}\right)$ with the same flow rate and duration, the XRD pattern was fypical 
of metallic iron with very sharp peaks, indicating large crystallite size. On the other hand, reduction at even higher temperature $\left(280^{\circ} \mathrm{C}\right)$ and of longer duration $(8 \mathrm{~h})$, but at lower flow rate, resulted in formation of metallic iron and magnetite (Fig. 9d). These results imply that high flow rate of $\mathrm{H}_{2}$ is needed for complete reduction of iron in the catalyst.

Figure 10 shows the XRD patterns of the $100 \mathrm{Fe} / 0.3 \mathrm{Cu} / 0.8 \mathrm{~K}$ catalyst reduced with (a) $\mathrm{CO}$ at $280^{\circ} \mathrm{C}$ for $8 \mathrm{~h}$, (b) $\mathrm{H}_{2} / \mathrm{CO}=2$ at $310^{\circ} \mathrm{C}$ for $6 \mathrm{~h}$, and (c) $\mathrm{H}_{2} / \mathrm{CO}=0.67$ at $280^{\circ} \mathrm{C}$ for $8 \mathrm{~h}$. In all three cases $\chi$-carbide $\left(\mathrm{Fe}_{5} \mathrm{C}_{2}\right)$ was identified as the dominant phase.

\section{X-Ray Diffraction of Used Catalysts from Fixed Bed Reactor}

Figure 11 shows XRD patterns of used catalysts from top and bottom parts of a fixed bed reactor. Nominal catalyst composition and reduction conditions are listed in Table 10 . No significant difference in the patterns was found between catalyst samples from top and bottom parts, indicating that phases were uniform throughout the reactor. With $\mathrm{H}_{2}$ reductions, the main phase in used catalysts was always iron carbide(s), as shown in Fig. 11 (a) and (b). A small peak of metallic iron was found in a sample from Run FB-3221 from top part of the reactor (a-1). On the other hand, in the case of CO reduction (Fig. 11 (c) and (d)), magnetite was identified as the main phase in used catalysts. With increasing silica content, the peak intensity decreased, probably because of smaller crystallite sizes of the original iron phases.

\section{Mössbauer Effect Spectroscopy (MES)}

We have sent 39 catalyst samples to the University of Kentucky (CFFLS) for characterization by MES, but have not received any results yet. 


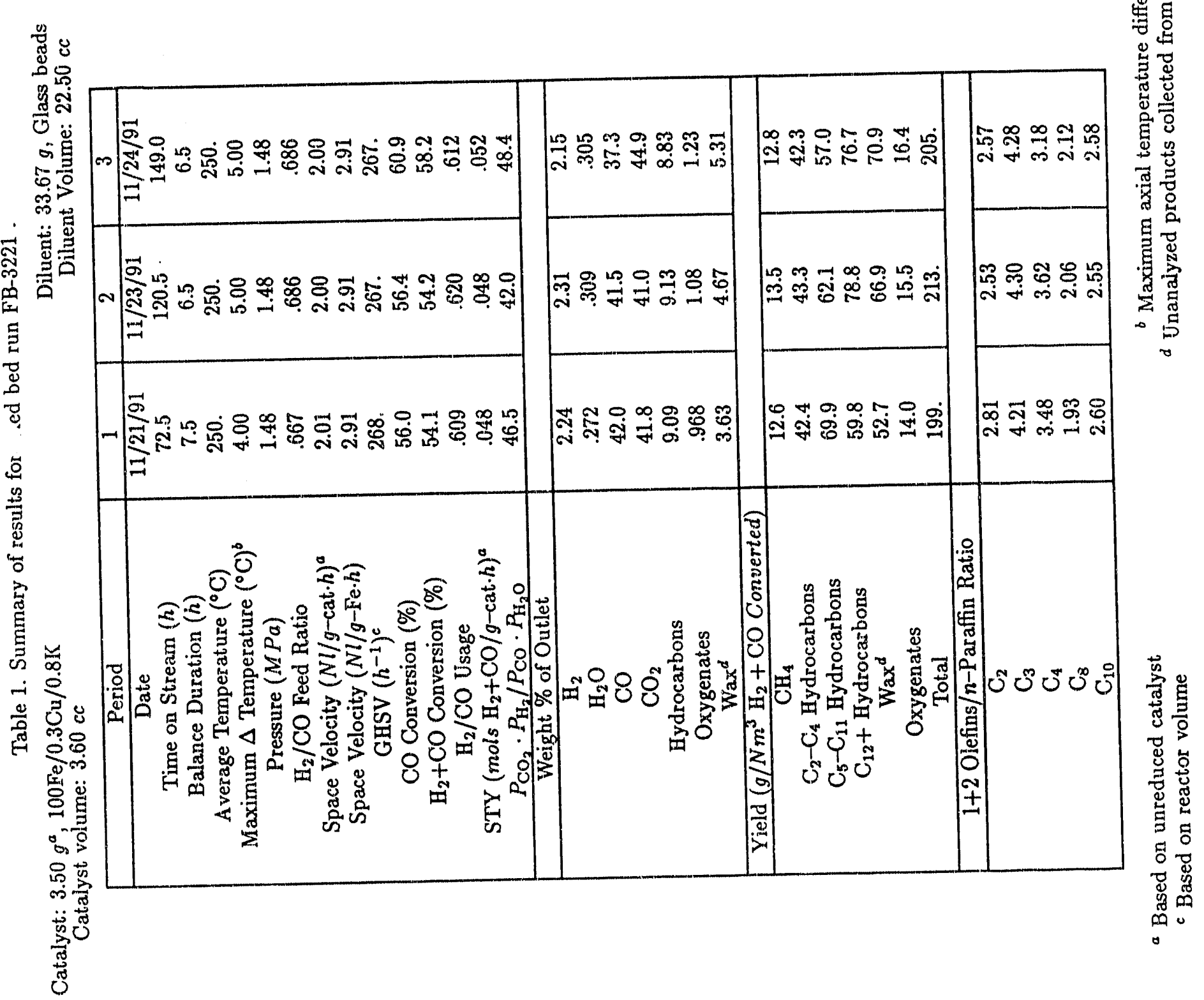




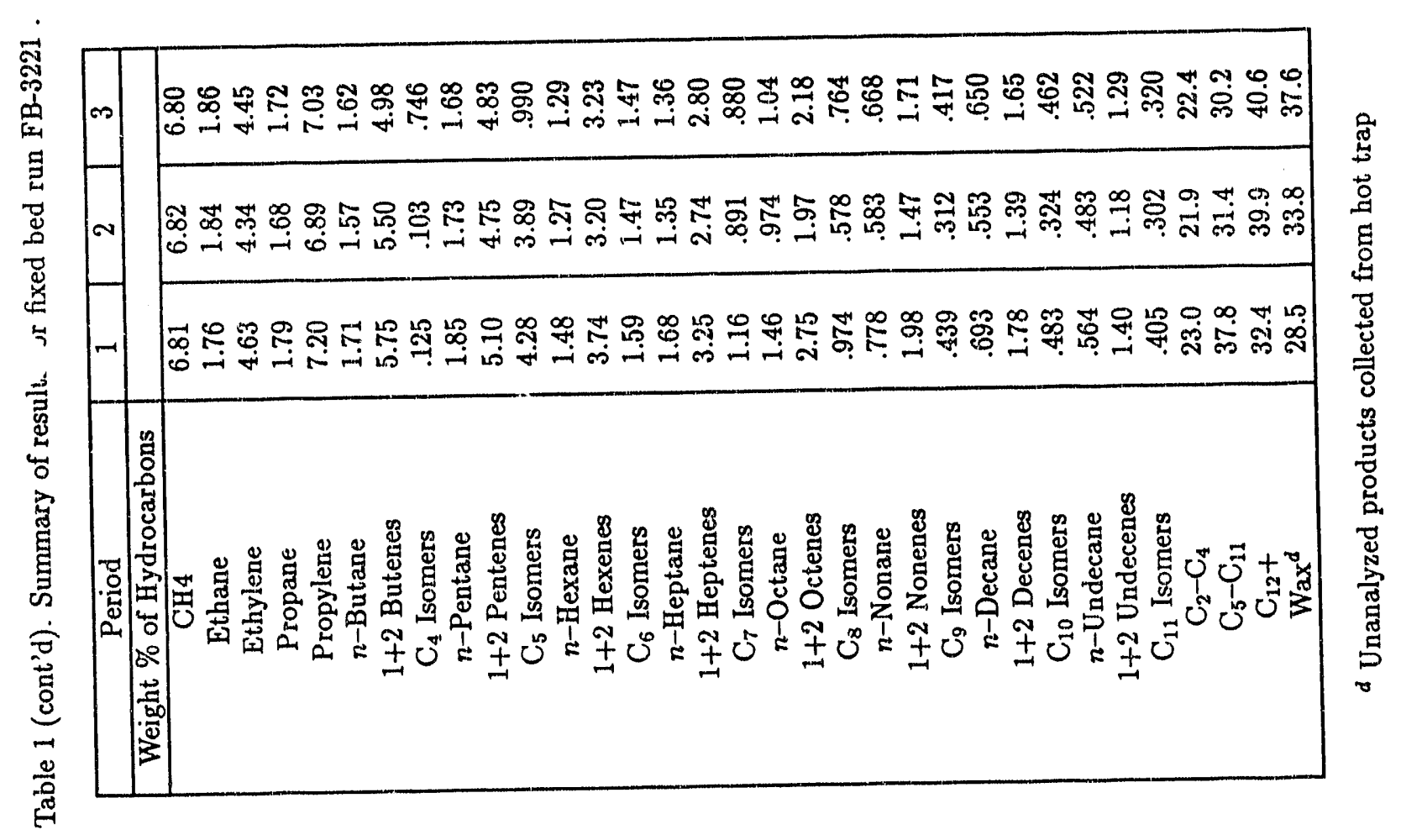




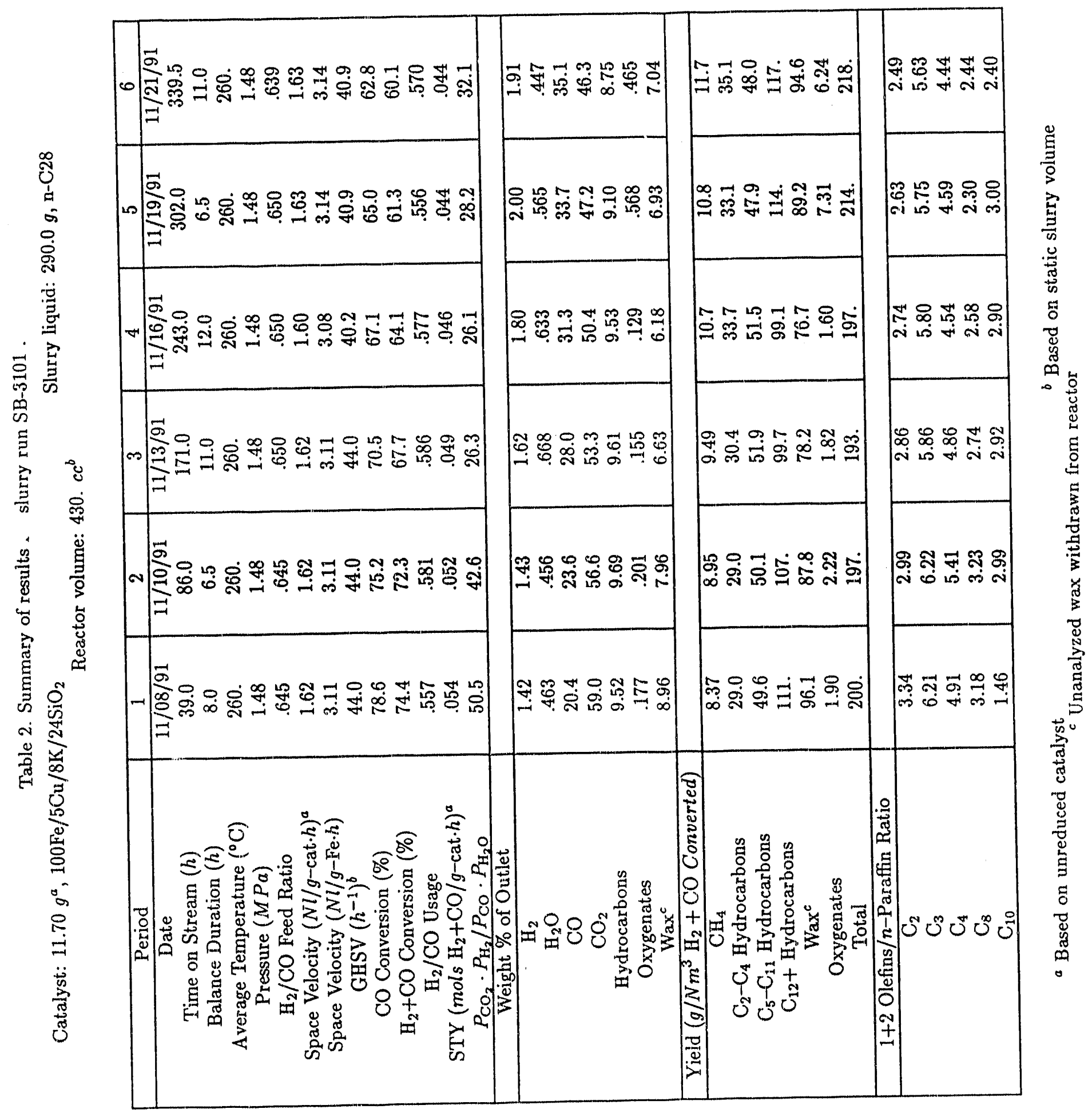




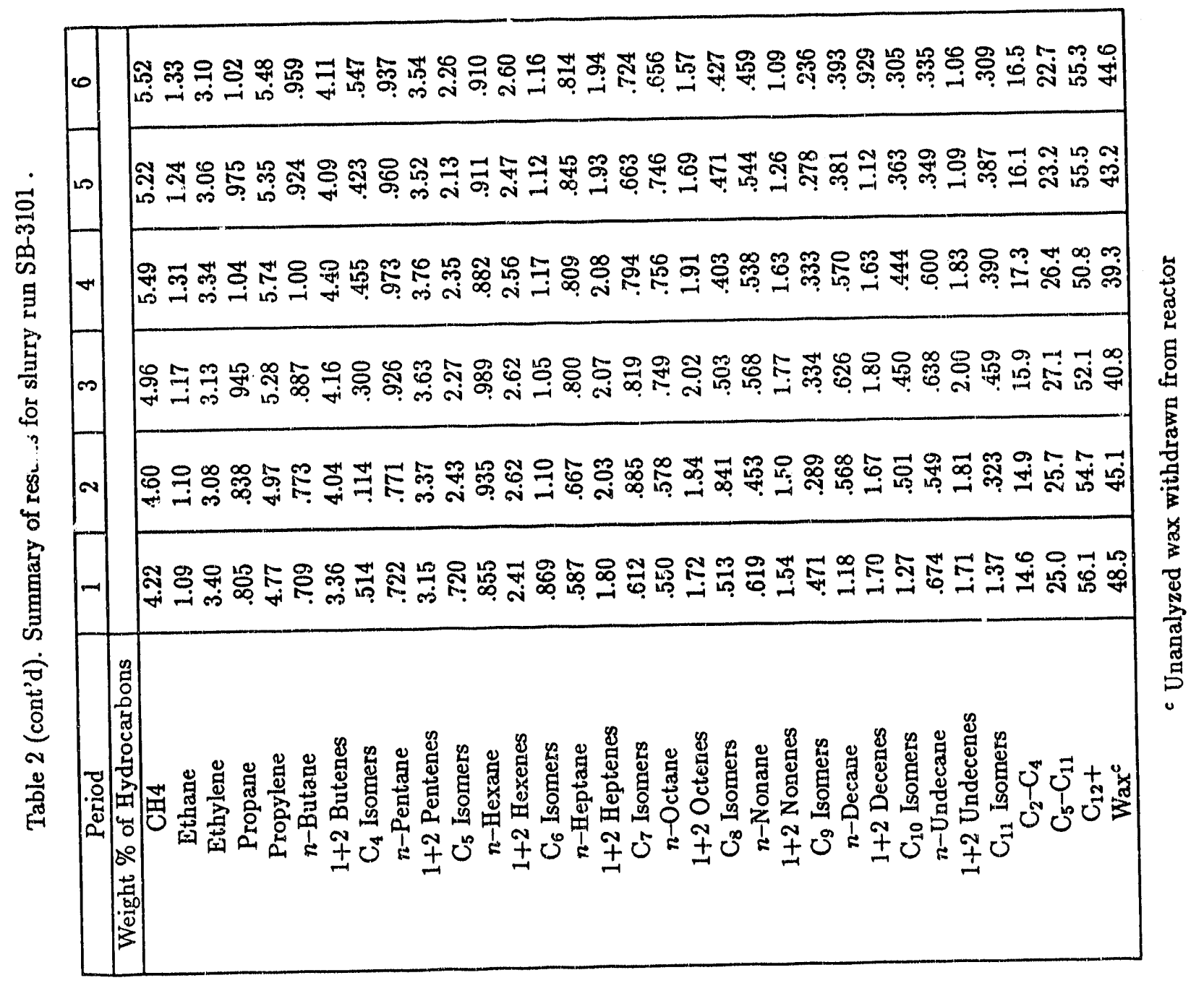


Table 3. Major events in Run SB-3101

TOS (h)

Event

Slurry loading: $310 \mathrm{~g}$ n-octacosane, $12.5 \mathrm{~g}$ catalyst (particle size $<270 \mathrm{mesh}$ )

Catalyst pretreatment: $\mathrm{H}_{2}$ at $250^{\circ} \mathrm{C}$

Slurry sample withdrawal: $20.4 \mathrm{~g}$ wax, $0.8 \mathrm{~g}$ catalyst

Wax withdrawal through filter: $6.31 \mathrm{~g}$ of wax

$0 \quad$ Initiate synthesis gas flow

1 Achieved process conditions: $\mathrm{T}=260^{\circ} \mathrm{C}, \mathrm{P}=1.48 \mathrm{MPa}, \mathrm{SV}=1.6 \mathrm{Nl} / \mathrm{g}-\mathrm{cat} / \mathrm{h}$, $\left(\mathrm{H}_{2} / \mathrm{CO}=0.64\right)$

158 Discovered decrease in feed flow rate and restored to desired flow rate

182 Slurry sample withdrawal: $24.5 \mathrm{~g}$ wax, $0.9 \mathrm{~g}$ catalyst

352 Slurry sample withdrawal: $49.3 \mathrm{~g}$ wax, $1.4 \mathrm{~g}$ catalyst

354 End of run: $287 \mathrm{~g}$ wax, $8.5 \mathrm{~g}$ catalyst recovered from reactor

Wax/catalyst removed during the run: $400 \mathrm{~g}$ of wax, $2.3 \mathrm{~g}$ of catalyst

Catalyst recovery: $92.3 \%$; Wax recovery: $101 \%$ 


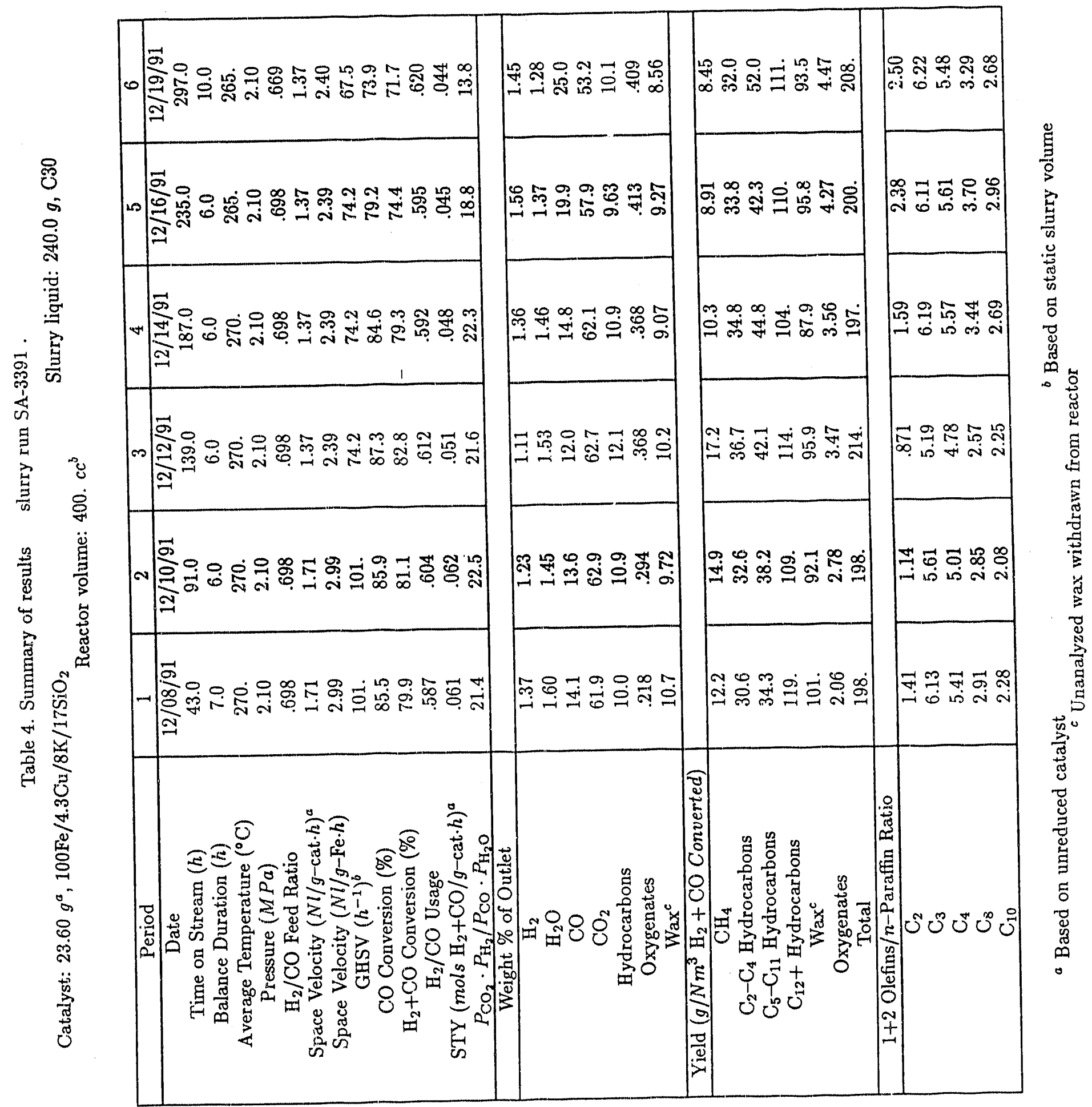




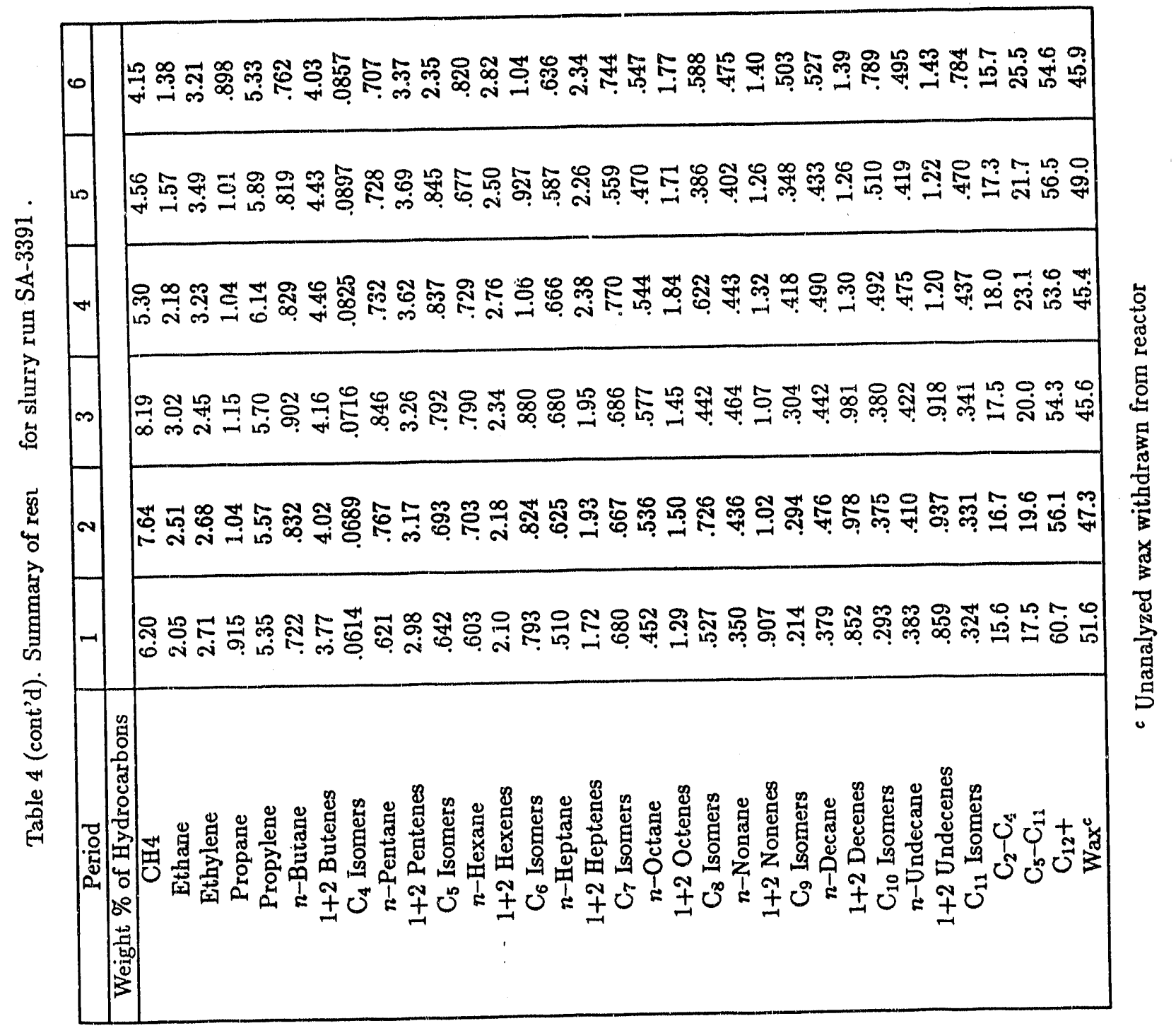


Table 5. Major events in Run SA-3391

$\operatorname{TOS}(\mathrm{h})$

Event

Slurry loading: $335 \mathrm{~g}$ ethylflo 164 (C30) liquid, $25.0 \mathrm{~g}$ catalyst (particle size $<270$ mesh)

Catalyst pretreatment: $\mathrm{H}_{2} / \mathrm{CO}=0.70, \mathrm{~T}=285^{\circ} \mathrm{C}, \mathrm{P}=1.14 \mathrm{MPa}, \mathrm{SV}=2.0 \mathrm{Nl} / \mathrm{g}-\mathrm{Fe} / \mathrm{h}$, for $12 \mathrm{~h}$

Slurry sample withdrawal: $18.7 \mathrm{~g}$ wax, $1.4 \mathrm{~g}$ catalyst,temperature was lowered from 285 to $270^{\circ} \mathrm{C}$ over $3 \mathrm{~h}$

Wax withdrawal through filter: $81.0 \mathrm{~g}$ of wax

$0 \quad$ Achieved process conditions: $\mathrm{T}=270^{\circ} \mathrm{C}, \mathrm{P}=2.10 \mathrm{MPa}, \mathrm{SV}=3.0 \mathrm{~N} / \mathrm{g}-\mathrm{Fe} / \mathrm{h}$, feed $\left(\mathrm{H}_{2} / \mathrm{CO}\right)=0.70$

98 Slurry sample withdrawal: $25 \mathrm{~g}$ wax, $1.9 \mathrm{~g}$ catalyst

101 Space velocity change from 3.0 to $2.4 \mathrm{~N} / \mathrm{g}-\mathrm{Fe} / \mathrm{h}$

173 Lowered reactor head $\left(270 \rightarrow 230^{\circ} \mathrm{C}\right)$ and exit line temperature $\left(250 \rightarrow 210^{\circ} \mathrm{C}\right)$

196 Slurry temperature was lowered from $270^{\circ} \mathrm{C}$ to $265^{\circ} \mathrm{C}$

265 Slurry sample withdrawal: $25 \mathrm{~g}$ wax, $2.0 \mathrm{~g}$ catalyst

287 Feed gas changed to $\left(\mathrm{H}_{2} / \mathrm{CO}\right)=0.67$

310 End of run: $288 \mathrm{~g}$ slurry recovered from the reactor

Wax/catalyst removed during the run: $726 \mathrm{~g}$ of wax $3.9 \mathrm{~g}$ of catalyst 
Table 6. Catalyst Composition Determined by Atomic Absorption

\begin{tabular}{lcccc}
\hline $\begin{array}{l}\text { Nominal Composition } \\
100 \mathrm{Fe} / \mathrm{xCu} / \mathrm{yK} / \mathrm{zSiO}_{2}\end{array}$ & $\mathrm{ID} \mathrm{\#}$ & $\mathrm{x}$ & $\mathrm{y}$ & $\left.\mathrm{z}^{*}\right)$ \\
\hline $100 \mathrm{Fe} / 5 \mathrm{Cu} / 4.2 \mathrm{~K} / 40 \mathrm{SiO}_{2}$ & $\# 63.2$ & $5.6 \pm 0.5$ & $6.7 \pm 0.5$ & $38 \pm 9$ \\
& & $(5.1 \pm 0.5$ & $6.6 \pm 0.8$ & $39 \pm 5)$ \\
$100 \mathrm{Fe} / 5 \mathrm{Cu} / 100 \mathrm{SiO}_{2}$ & $\mathrm{~S} 5000-1$ & $5.4 \pm 0.5$ & $4.6 \pm 0.5$ & $112 \pm 10$ \\
& & $(5.0 \pm 0.4$ & $4.4 \pm 0.5$ & $112 \pm 8)$ \\
$100 \mathrm{Fe} / 5 \mathrm{Cu} / 100 \mathrm{SiO}_{2}$ & $\mathrm{~S} 5000-2$ & $5.3 \pm 0.5$ & $2.1 \pm 0.3$ & $105 \pm 10$ \\
$100 \mathrm{Fe} / 5 \mathrm{Cu} / 100 \mathrm{SiO}_{2}$ & $\mathrm{~S} 5000-4$ & $5.2 \pm 0.5$ & $1.1 \pm 0.1$ & $104 \pm 10$ \\
$100 \mathrm{Fe} / 5 \mathrm{Cu} / 4.2 \mathrm{~K} / 100 \mathrm{SiO}_{2}$ & $\# 69$ & $5.0 \pm 0.4$ & $9.4 \pm 1.1$ & $95 \pm 10$ \\
& & $(4.6$ & 2.7 & $95 \pm 8)$ \\
& & $(4.6 \pm 0.4$ & $8.0 \pm 1.0$ & $31 \pm 9$ \\
$\mathrm{Ruhrchemie}$ catalyst & $\# 99$ & $5.6 \pm 0.5$ & $5.1 \pm 0.6$ & $30 \pm 8)$ \\
\hline
\end{tabular}

*) Estimated by calculation, by determining contents of $\mathrm{Fe}, \mathrm{Cu}$ and $\mathrm{K}$, and by assuming that the remainder is $\mathrm{SiO}_{2}$.

( ) Previous results.

[] Determined by Galbraith Lab. Inc.

Table 7. BET and PSD Result of Calcined Catalyst Samples

\begin{tabular}{ccccc}
\hline $\begin{array}{c}\text { Catalyst } \\
\text { composition }\end{array}$ & $\begin{array}{c}\text { Catalyst } \\
\text { Code }\end{array}$ & $\begin{array}{c}\left.\mathrm{SA}^{\mathrm{a}}\right) \\
\left(\mathrm{m}^{2} / \mathrm{g}\right)\end{array}$ & $\begin{array}{c}\mathrm{V}_{\mathrm{p}}^{\mathrm{b}} \\
(\mathrm{cc} / \mathrm{g})\end{array}$ & $\begin{array}{c}\overline{\mathrm{d}}_{\mathrm{p}}^{\mathrm{c}} \\
(\AA)\end{array}$ \\
\hline \hline $100 \mathrm{Fe} / 0.3 \mathrm{Cu} / 0.8 \mathrm{~K}$ & $\mathrm{C} 0308-1$ & $151.5 \pm 1.1$ & 0.26 & 69 \\
$100 \mathrm{Fe} / 0.3 \mathrm{Cu} / 0.8 \mathrm{~K}$ & $\mathrm{C} 0308-3 \mathrm{~d})$ & $129.6 \pm 1.5$ & 0.33 & 101 \\
$100 \mathrm{Fe} / 5 \mathrm{Cu} / 4.2 \mathrm{~K} / 100 \mathrm{SiO}_{2}$ & $\# 69$ & $149.7 \pm 0.2$ & 0.83 & 222 \\
\hline
\end{tabular}
a) Surface area.
b) Pore Volume.
c) $\bar{d}_{\mathrm{p}}=4 \times V_{\mathrm{p}} / \mathrm{SA}$.
d) Reported in Quarterly Report \#7 (April - June, 1991). 
Table 8. X-ray Diffraction Analysis of Fresh Catalysts

\begin{tabular}{lcclc}
\hline \multicolumn{1}{c}{ Catalyst } & Composition & Gas Temperature & Phase & $\begin{array}{c}\text { Crystallite } \\
\text { size }(\AA)\end{array}$ \\
\hline C-0308-1 & $100 \mathrm{Fe} / 0.3 \mathrm{Cu} / 0.8 \mathrm{~K}$ & as-prepared & $\mathrm{Fe}_{2} \mathrm{O}_{3}(?)$ & $*$ \\
$\mathrm{C}-0308-1$ & $100 \mathrm{Fe} / 0.3 \mathrm{Cu} / 0.8 \mathrm{~K}$ & calcined & $\mathrm{Fe}_{2} \mathrm{O}_{3}$ & $160-190$ \\
$\mathrm{C}-0308-3$ & $100 \mathrm{Fe} / 0.3 \mathrm{Cu} / 0.8 \mathrm{~K}$ & as-prepared & $\mathrm{Fe}_{2} \mathrm{O}_{3}$ & $240-270$ \\
$\left.\mathrm{C} 0308-3^{* *}\right)$ & $100 \mathrm{Fe} / 0.3 \mathrm{Cu} / 0.8 \mathrm{~K}$ & calcined & $\mathrm{Fe}_{2} \mathrm{O}_{3}$ & $220-370$ \\
Ruhrchemie LP33/81 & & as-prepared & $\mathrm{Fe}_{2} \mathrm{O}_{3}$ & $*$ \\
Ruhrchemie LP33/81 & & calcined & $\mathrm{Fe}_{2} \mathrm{O}_{3}$ & $*$ \\
UCI & & as-prepared & $\mathrm{Fe}_{2} \mathrm{O}_{3}$ & 470 \\
\hline
\end{tabular}

*) The peaks were too broad to determine the crystallite size.

**) Reported in Quarterly Report \#7 (April - June, 1991).

Table 9. X-Ray Diffraction Analysis of Reduced $100 \mathrm{Fe} / 0.3 \mathrm{Cu} / 0.8 \mathrm{~K}$ Catalyst

\begin{tabular}{ccccl}
\hline Gas & \multicolumn{3}{c}{ Reduction Conditions } & \\
& $\begin{array}{c}\text { Flow rate } \\
(\mathrm{m} / \text { min) }\end{array}$ & $\begin{array}{c}\text { Temp. } \\
(\mathrm{C})\end{array}$ & $\begin{array}{c}\text { Duration } \\
(\mathrm{h})\end{array}$ & \multicolumn{1}{c}{ Phase } \\
\hline \hline $\mathrm{H}_{2}$ & 3350 & 220 & 1 & $\mathrm{Fe}_{3} \mathrm{O}_{4}(+\mathrm{Fe})$ \\
$\mathrm{H}_{2}$ & 3350 & 250 & 2 & $\mathrm{Fe}$ \\
$\mathrm{H}_{2}$ & 85 & 280 & 8 & $\mathrm{Fe}_{3} \mathrm{O}_{4}+\mathrm{Fe}$ \\
$\mathrm{CO}$ & 85 & 280 & 8 & $\chi-\mathrm{Fe}_{2.5} \mathrm{C}\left(\mathrm{Fe}_{5} \mathrm{C}_{2}\right)$ \\
$\left(\mathrm{H}_{2} / \mathrm{CO}\right)=2$ & 1200 & 310 & 6 & $\chi-\mathrm{Fe}_{2.5} \mathrm{C}\left(\mathrm{Fe}_{5} \mathrm{C}_{2}\right)$ \\
$\left(\mathrm{H}_{2} / \mathrm{CO}\right)=0.67$ & 85 & 280 & 8 & $\chi-\mathrm{Fe}_{2.5} \mathrm{C}\left(\mathrm{Fe}_{5} \mathrm{C}_{2}\right)$ \\
\hline \hline
\end{tabular}

Table 10. X-Ray Diffraction Analysis of Used Catalysts from Fixed Bed Reactor

\begin{tabular}{ccccccc}
\hline \multirow{2}{*}{ Run \# } & Location & Catalyst & \multicolumn{3}{c}{ Reduction Condition } \\
& Composition & Gas & $\mathrm{T}\left({ }^{\circ} \mathrm{C}\right)$ & $\mathrm{t}(\mathrm{h})$ & Phase \\
\hline FB-3221 & (top) & $100 \mathrm{Fe} / 0.3 \mathrm{Cu} / 0.8 \mathrm{~K}$ & $\mathrm{H}_{2}$ & 280 & 8 & $\mathrm{Fe}_{2} \mathrm{C}$ \\
& & & & & & $\mathrm{Fe}$ \\
FB-3221 & (bottom) & $\uparrow$ & $\uparrow$ & $\uparrow$ & $\uparrow$ & $\mathrm{Fe}_{2} \mathrm{C}$ \\
FA-0959 & & $100 \mathrm{Fe} / 5 \mathrm{Cu} / 4.2 \mathrm{~K} / 16 \mathrm{SiO}_{2}$ & $\mathrm{H}_{2}$ & 220 & 8 & $\mathrm{Fe}_{\mathbf{x}} \mathrm{C}$ \\
FB-2671 & (top) & $100 \mathrm{Fe} / 5 \mathrm{Cu} / 4.2 \mathrm{~K} / 40 \mathrm{SiO}_{2}$ & $\mathrm{CO}$ & 280 & 12 & $\mathrm{Fe}_{3} \mathrm{O}_{4}$ \\
FB-2671 & (bottom) & $\uparrow$ & $\uparrow$ & $\uparrow$ & $\uparrow$ & $\mathrm{Fe}_{3} \mathrm{O}_{4}$ \\
FB-2391 & (top) & $100 \mathrm{Fe} / 5 \mathrm{Cu} / 4.2 \mathrm{~K} / 100 \mathrm{SiO}_{2}$ & $\mathrm{CO}$ & 280 & 12 & $\mathrm{Fe}_{3} \mathrm{O}_{4}$ \\
FB-2391 & (bottom) & $\uparrow$ & $\uparrow$ & $\uparrow$ & $\uparrow$ & $\mathrm{Fe}_{3} \mathrm{O}_{4}$ \\
\hline \hline
\end{tabular}




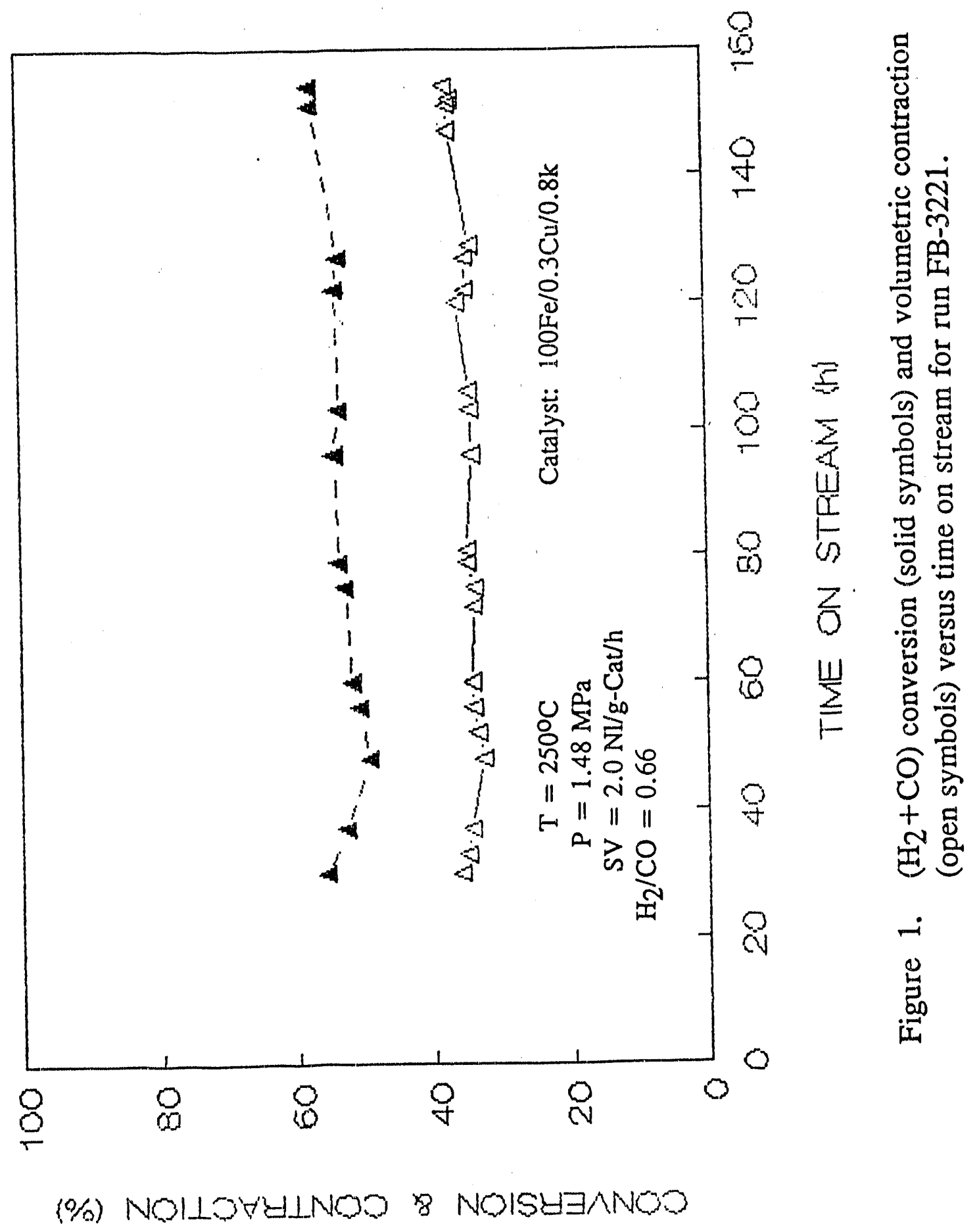




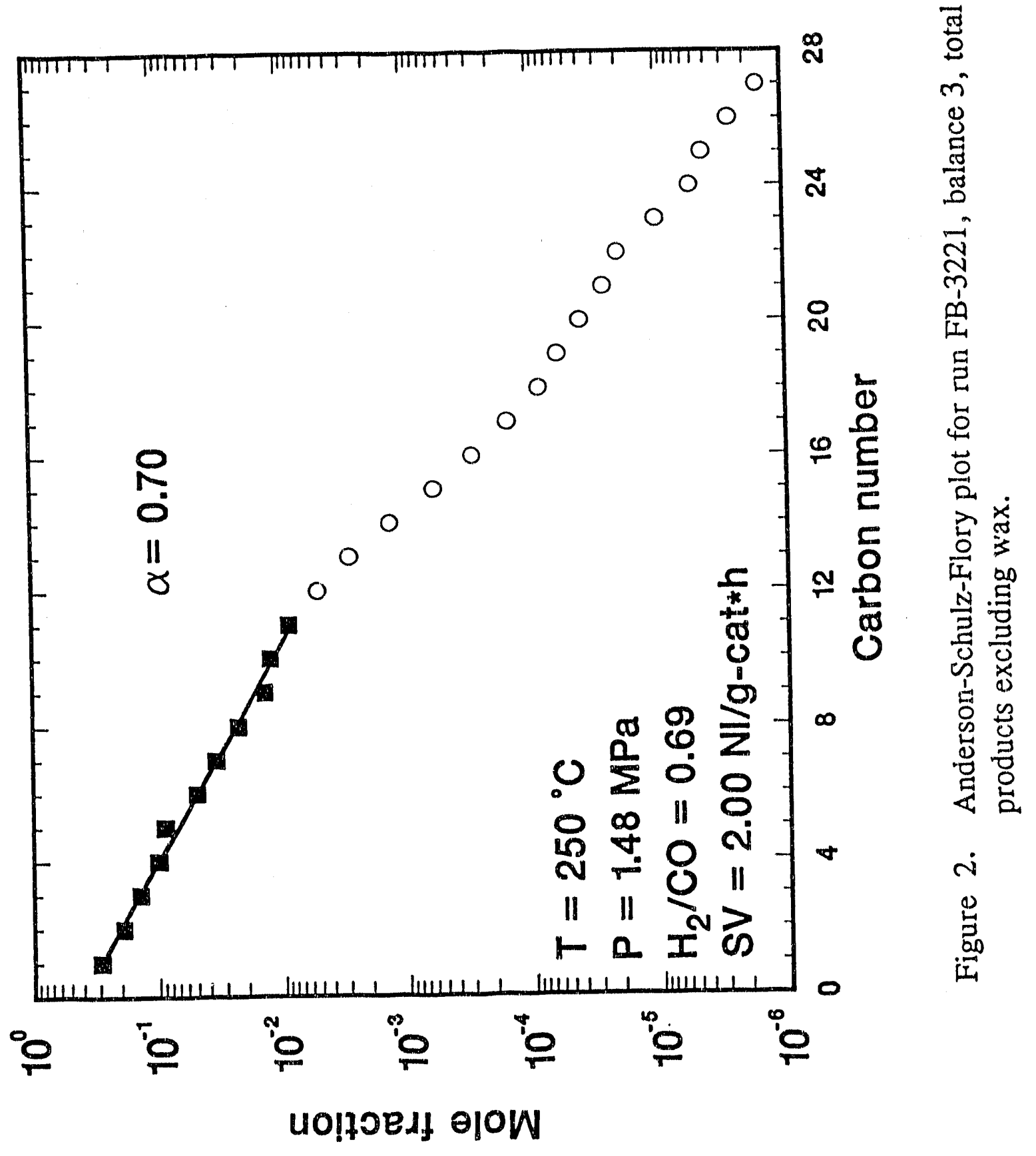




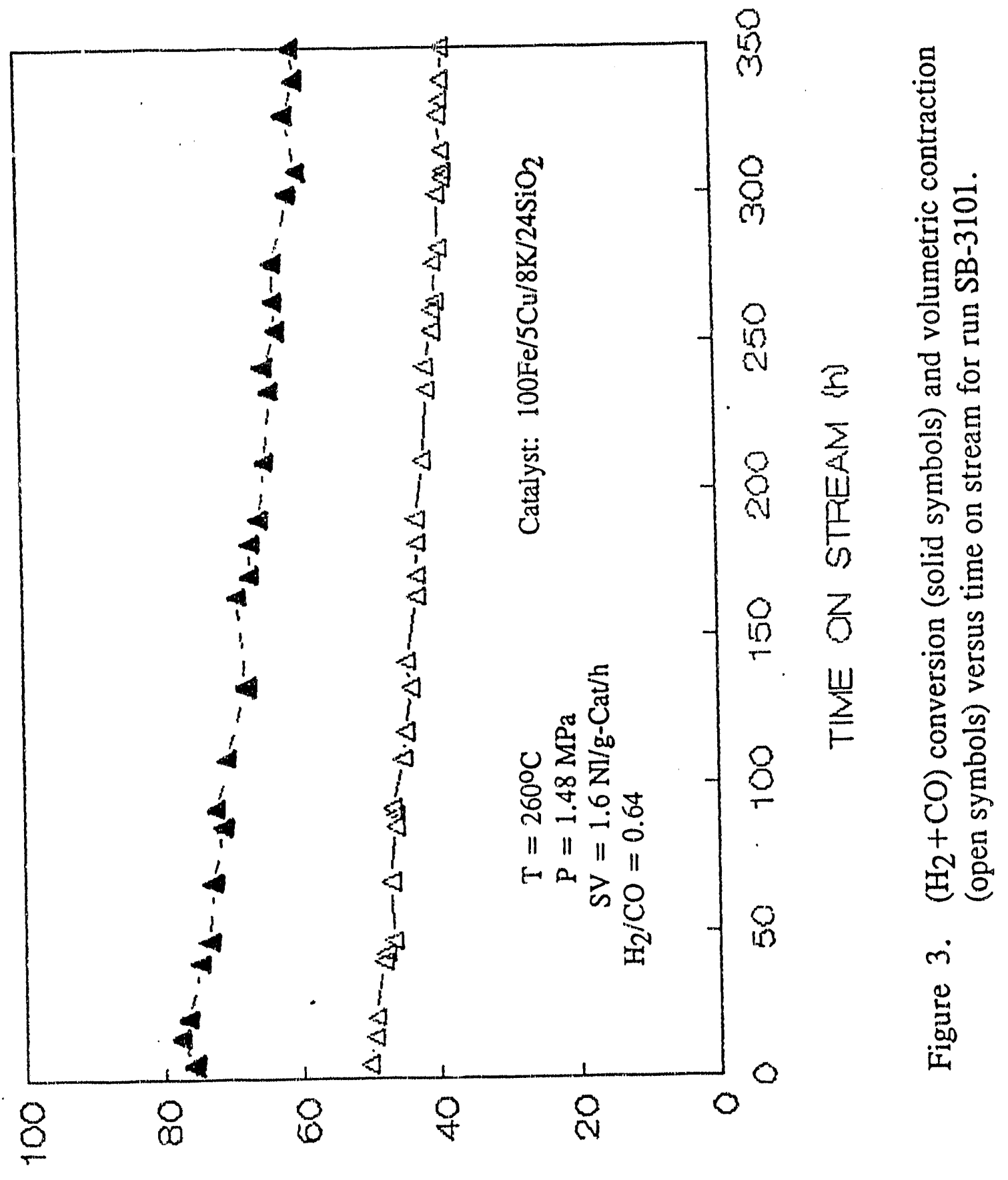

(\%) NOLLOH 


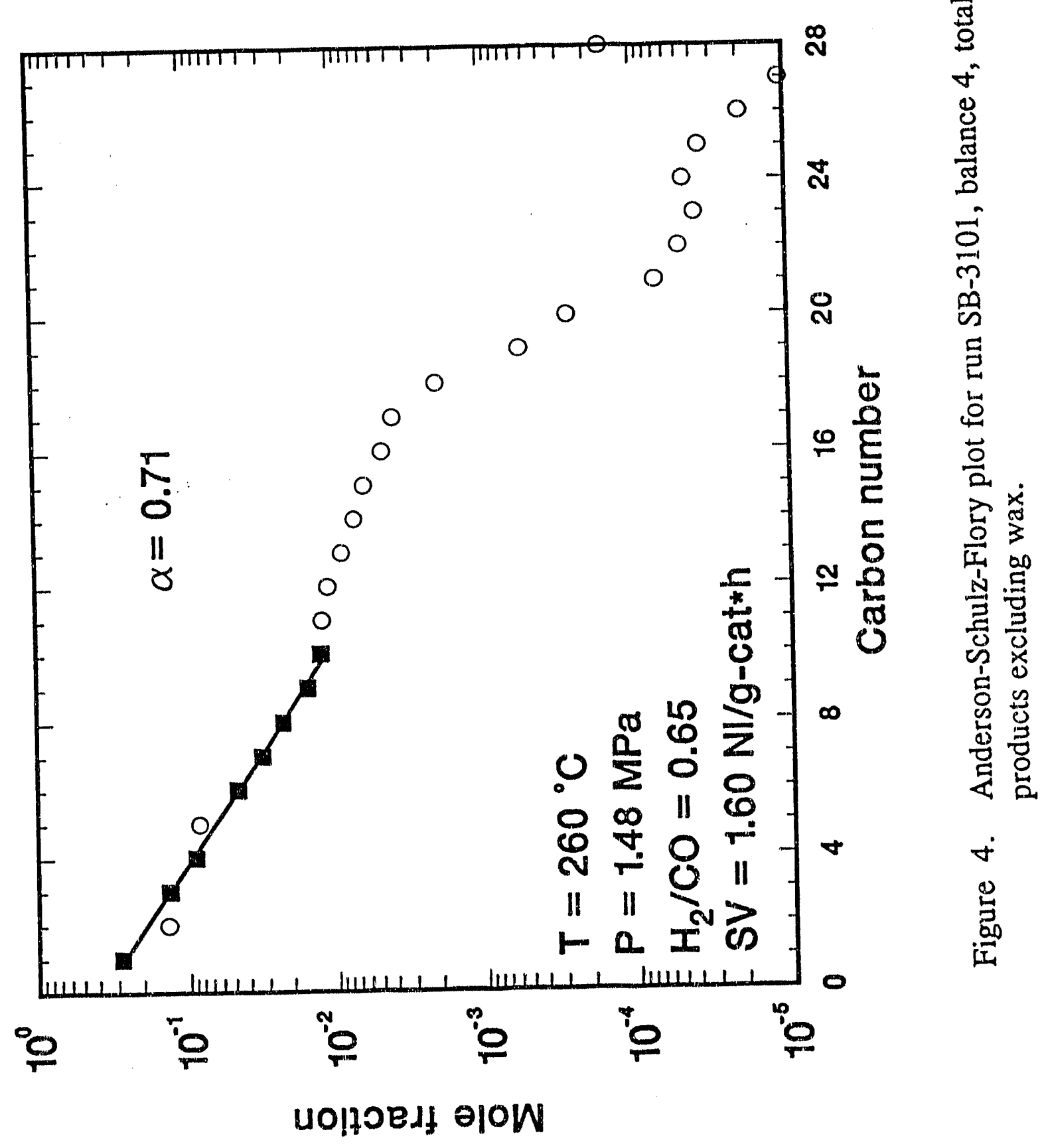




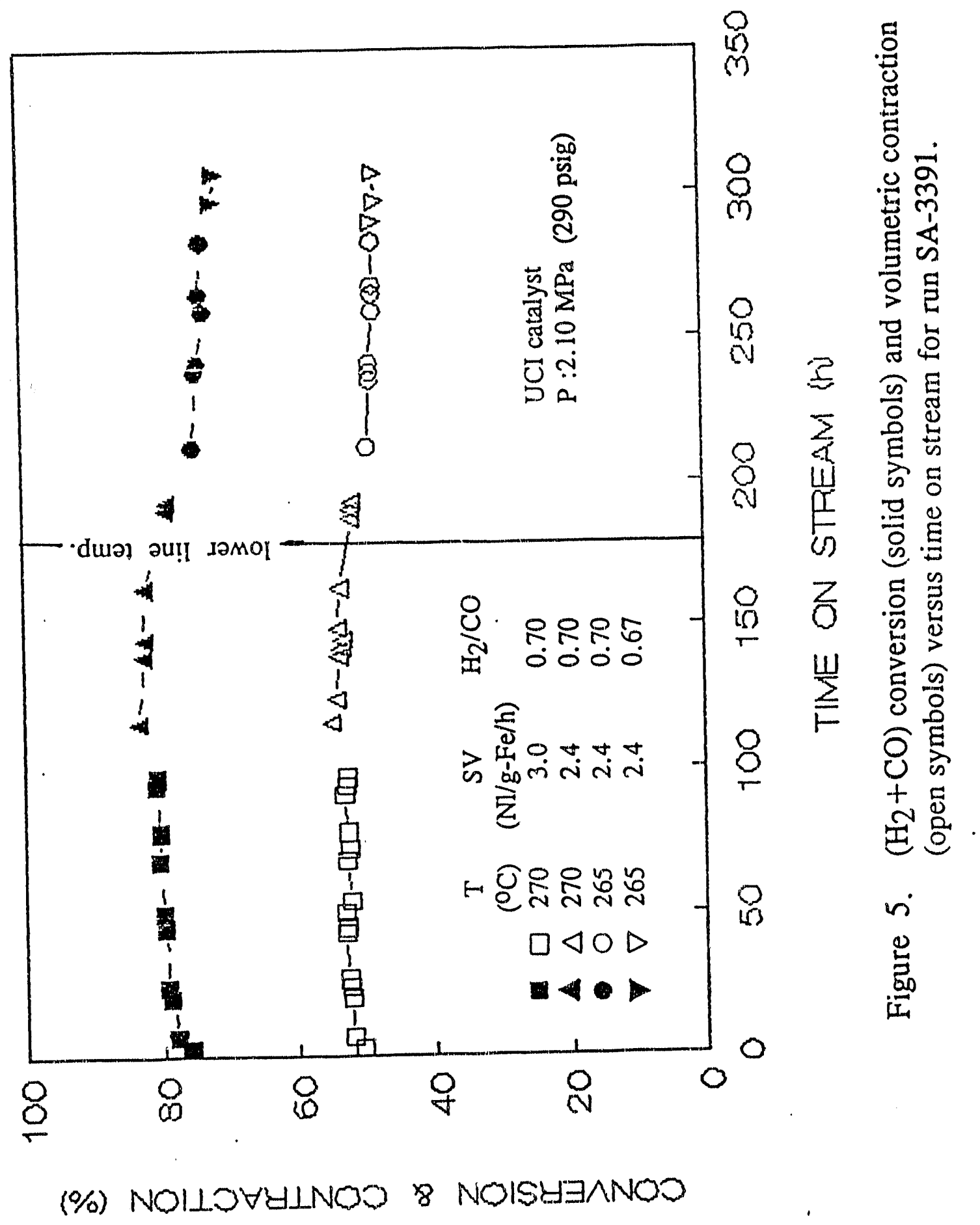




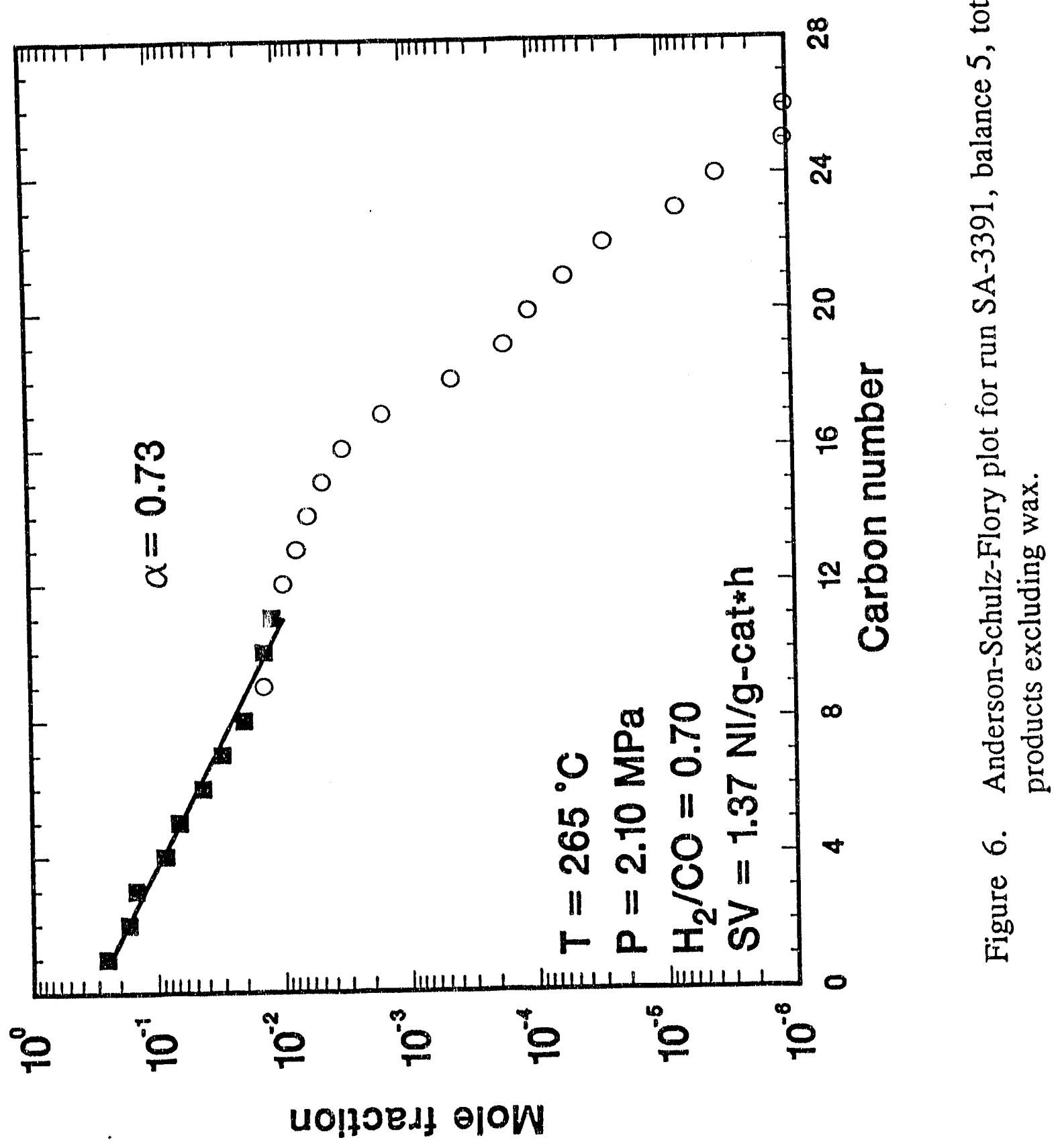



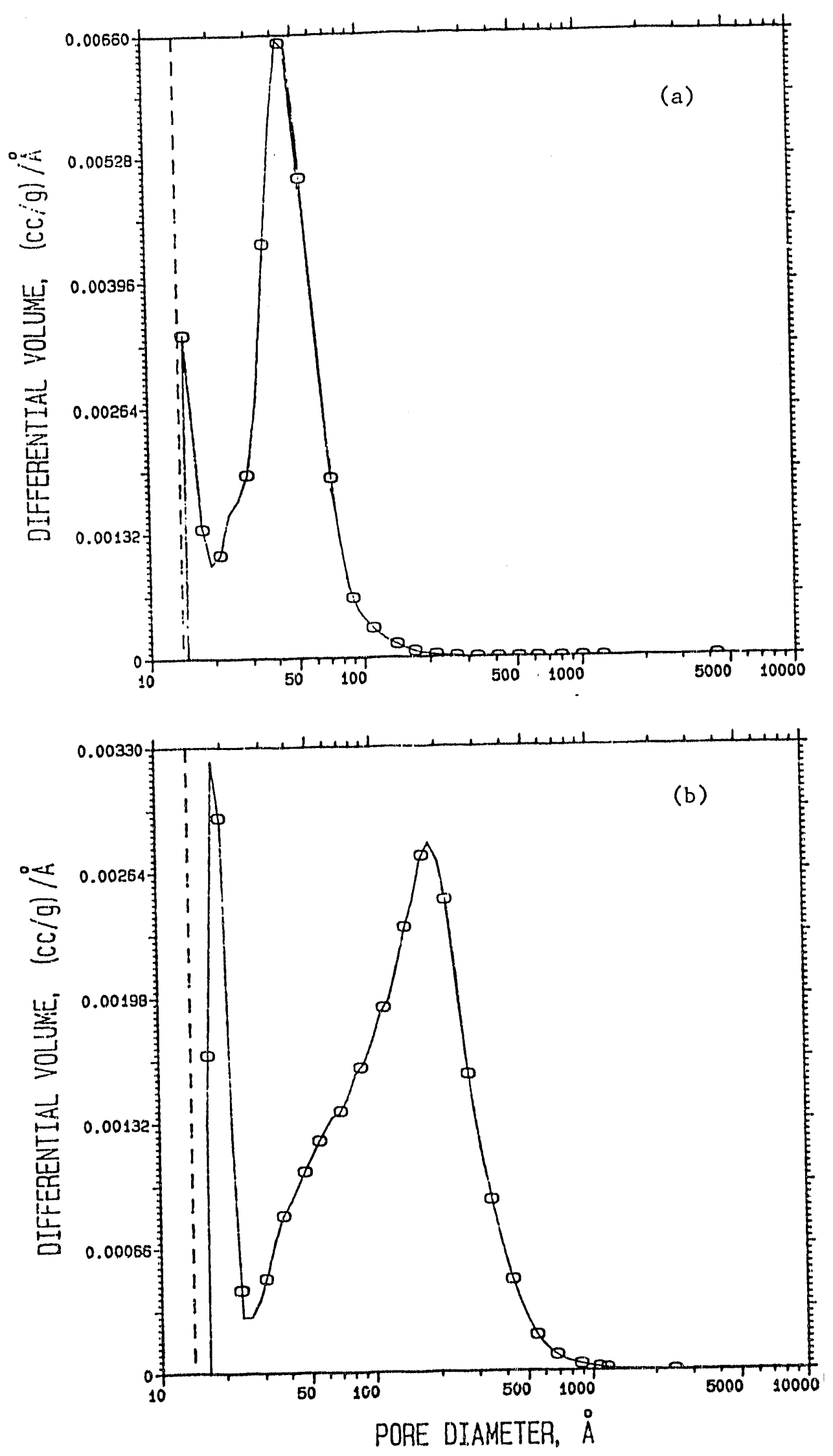

Fig. 7 Differential Pore Volume Distribution of Calcined Catalysts.
(a) $100 \mathrm{Fe} / 0.3 \mathrm{Cu} / 0.8 \mathrm{~K}$,
(b) $100 \mathrm{Fe} / 5 \mathrm{Cu} / 4.2 \mathrm{~K} / 100 \mathrm{SiO}_{2}$. 

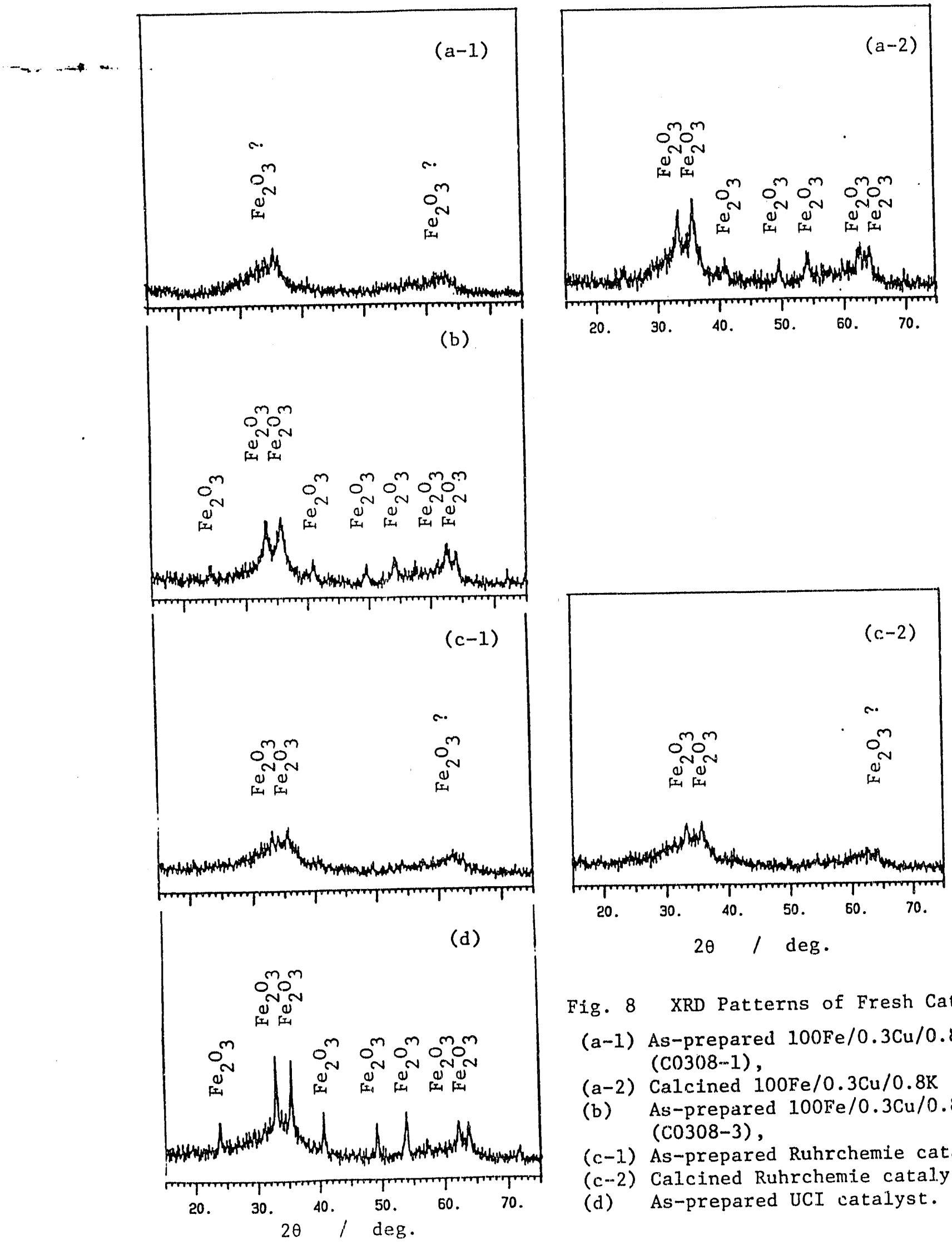

Fig. 8 XRD Patterns of Fresh Catalysts $(\mathrm{a}-1)$ As-prepared $100 \mathrm{Fe} / 0.3 \mathrm{Cu} / 0.8 \mathrm{~K}$ (CO308-1),

(a-2) Calcined $100 \mathrm{Fe} / 0.3 \mathrm{Cu} / 0.8 \mathrm{~K}(\mathrm{C} 0308-1)$,

(b) As-prepared $100 \mathrm{Fe} / 0.3 \mathrm{Cu} / 0.8 \mathrm{~K}$ (c0308-3),

(c-1) As-prepared Ruhrchemie catalyst,

(c--2) Calcined Ruhrchemie catalyst, and

(d) As-prepared UCI catalyst. 


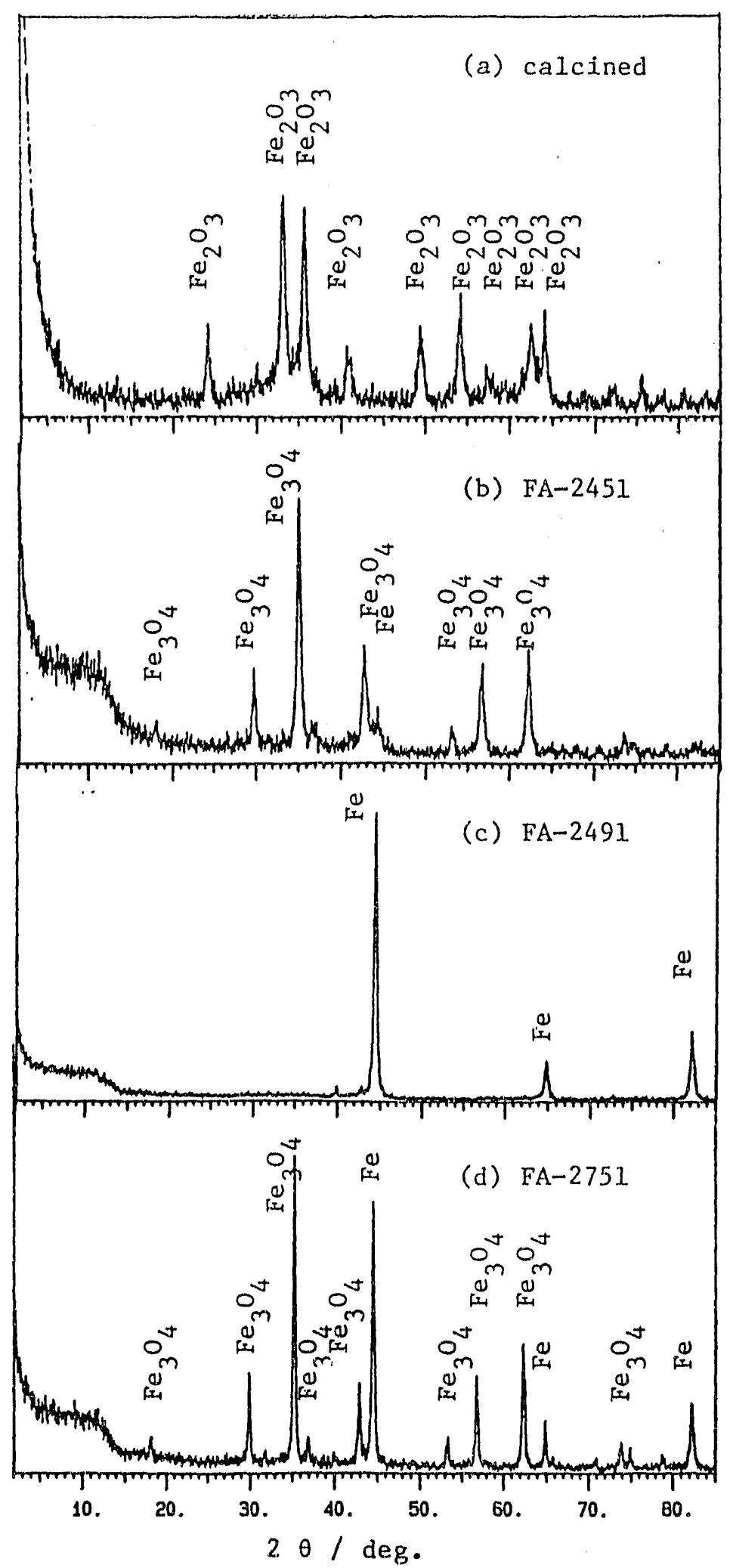

Fig. 9 XRD Pattern of $100 \mathrm{Fe} / 0.3 \mathrm{Cu} / 0.8 \mathrm{~K}$ Catalyst

(a) calcined, (b) reduced with $\mathrm{H}_{2}(3550 \mathrm{mI} / \mathrm{min})$ at $220^{\circ} \mathrm{C}$ for $1 \mathrm{~h}$,

(c) reduced with $\mathrm{H}_{2}(3350 \mathrm{ml} / \mathrm{min})$ at $250^{\circ} \mathrm{C}$ for $2 \mathrm{~h}$,

(d) reduced with $\mathrm{H}_{2}(85 \mathrm{ml} / \mathrm{min})$ at $280^{\circ} \mathrm{C}$ for $8 \mathrm{~h}$. 


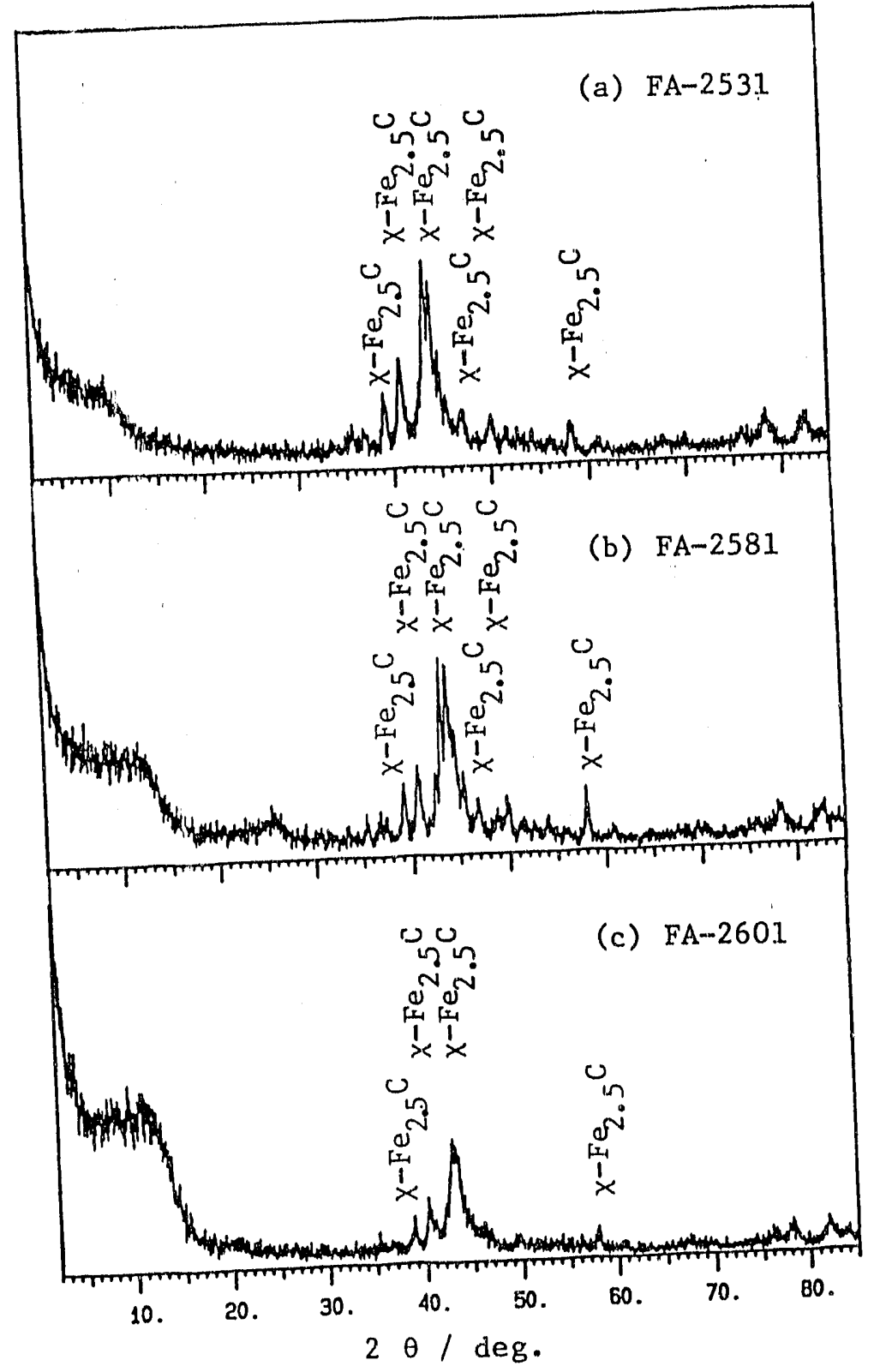

Fig.10 XRD Pattern of $100 \mathrm{Fe} / 0.3 \mathrm{Cu} / 0.8 \mathrm{~K}$ Catalyst Reduced with

(a) Co $(85 \mathrm{ml} / \mathrm{min})$ at $280^{\circ} \mathrm{C}$ for $8 \mathrm{~h}$,

(b) $\mathrm{H}_{2} / \mathrm{CO}=2(1200 \mathrm{ml} / \mathrm{min})$ at $310^{\circ} \mathrm{C}$ for $6 \mathrm{~h}$, and

(c) $\mathrm{H}_{2} / \mathrm{CO}=0.67(85 \mathrm{mI} / \mathrm{min})$ at $280^{\circ} \mathrm{C}$ for $8 \mathrm{~h}$. 


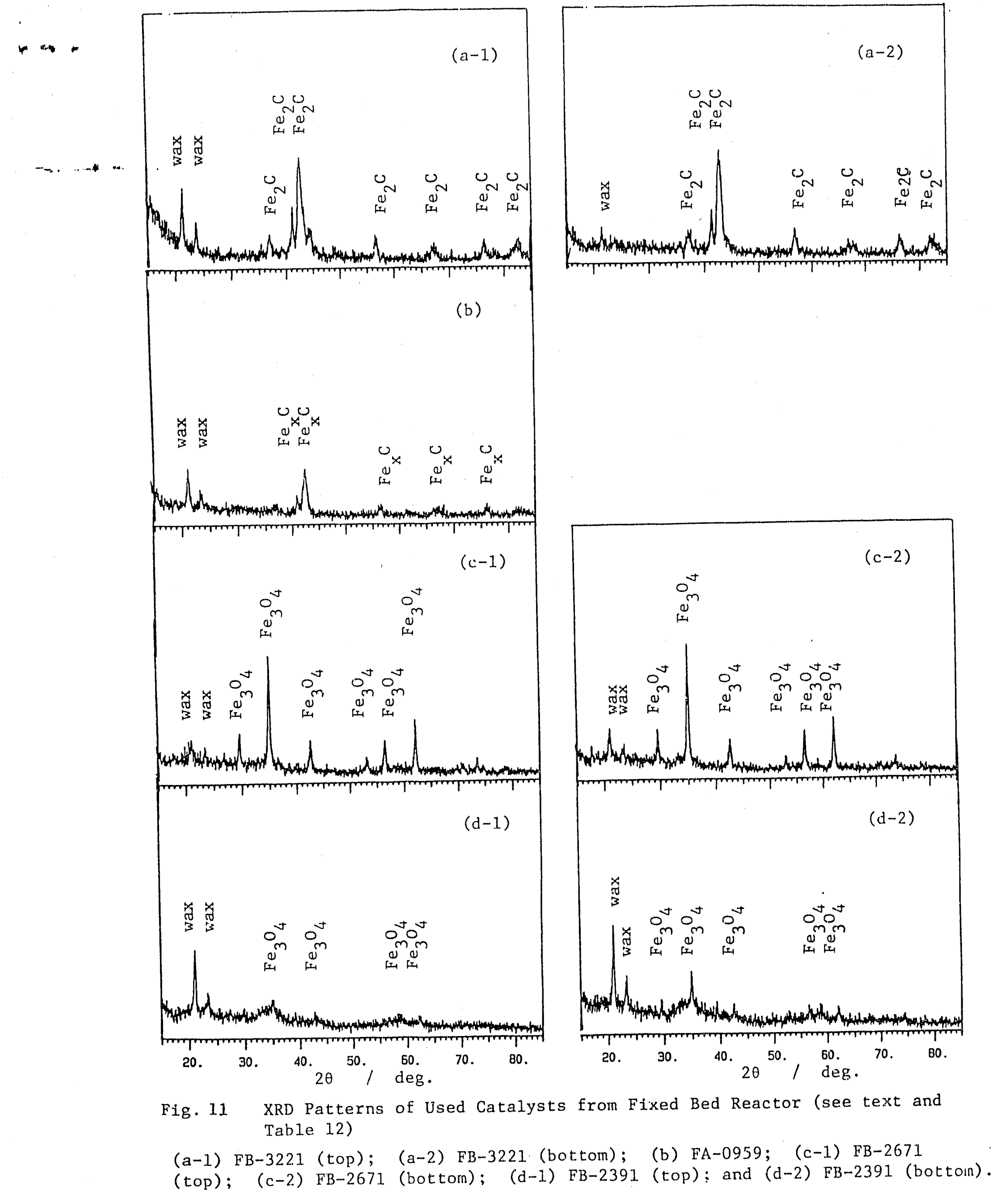


DATE FILMED $8117 / 92$ 
